\title{
Healthy cognitive ageing in the Lothian Birth Cohort studies: marginal gains not magic bullet
}

\author{
J. Corley ${ }^{1,2}$, S. R. Cox $^{1,2}$ and I. J. Deary ${ }^{1,2 *}$ \\ ${ }^{1}$ Department of Psychology, The University of Edinburgh, Edinburgh, UK \\ ${ }^{2}$ Centre for Cognitive Ageing and Cognitive Epidemiology, The University of Edinburgh, Edinburgh, UK
}

\begin{abstract}
In the face of shifting demographics and an increase in human longevity, it is important to examine carefully what is known about cognitive ageing, and to identify and promote possibly malleable lifestyle and health-related factors that might mitigate age-associated cognitive decline. The Lothian Birth Cohorts of 1921 (LBC1921, $n=550)$ and 1936 (LBC1936, $n=1091$ ) are longitudinal studies of cognitive and brain ageing based in Scotland. Childhood IQ data are available for these participants, who were recruited in later life and then followed up regularly. This overview summarises some of the main LBC findings to date, illustrating the possible genetic and environmental contributions to cognitive function (level and change) and brain imaging biomarkers in later life. Key associations include genetic variation, health and fitness, psychosocial and lifestyle factors, and aspects of the brain's structure. It addresses some key methodological issues such as confounding by early-life intelligence and social factors and emphasises areas requiring further investigation. Overall, the findings that have emerged from the LBC studies highlight that there are multiple correlates of cognitive ability level in later life, many of which have small effects, that there are as yet few reliable predictors of cognitive change, and that not all of the correlates have independent additive associations. The concept of marginal gains, whereby there might be a cumulative effect of small incremental improvements across a wide range of lifestyle and health-related factors, may offer a useful way to think about and promote a multivariate recipe for healthy cognitive and brain ageing.
\end{abstract}

Received 27 April 2017; Accepted 8 May 2017; First published online 9 June 2017

Key words: Cognitive ageing, brain imaging, genetic variation, health, intelligence, lifestyle factors.

\section{Introduction}

Promoting successful cognitive ageing is a topic of major importance to individuals and the field of public health. For most, losing one's cognitive abilities, especially memory, is feared more than physical disability (Martin, 2004). Cognitive decline in older age is associated with poorer health and quality of life (Plassman et al. 2010), impairments in functional activities, decision-making and independence (Tucker-Drob, 2011; Boyle et al. 2012; Jekel et al. 2015), and increased health care costs (Brayne, 2007). In the face of shifting demographics and an increase in human longevity, there is a pressing need to evaluate the potential contributions to cognitive function in later life. People differ in their cognitive abilities, both in terms of their overall level, and the rate at which they experience decline in older age (Gow et al. 2011). A key question is: why do some people have a better cognitive trajectory than others? Identifying factors that predispose individuals to a faster rate of cognitive decline is an important step

\footnotetext{
* Address for correspondence: Professor I. J. Deary, Centre for Cognitive Ageing and Cognitive Epidemiology, The University of Edinburgh, Edinburgh, EH8 9JZ, UK.

(Email: Ian.Deary@ed.ac.uk)
}

for developing intervention and treatment strategies aimed at maintaining cognitive and brain health into older age.

The main focus of the Lothian Birth Cohort (LBC) studies is people's differences in cognitive and brain ageing. The idea for these studies came about following the discovery of ledgers containing the results of the Scottish Mental Surveys (SMS) (Deary et al. 2009c). The surveys had tested the intelligence of almost a whole year-of-birth, twice. On 1 June 1932, almost every child born in 1921 and attending a Scottish school took the same general mental ability test, known as the Moray House Test (MHT) No. 12. The exercise was repeated on 4 June 1947 for almost every Scottish school pupil born in 1936. These were the SMS of 1932 and 1947. Most schools in Scotland participated, yielding test scores on 87498 (SMS1932) and 70805 (SMS1947) 11-year olds. From 1999, the LBC studies, based at the University of Edinburgh, recruited men and women in the Lothian region of Scotland who were surviving participants of the SMS of 1932 (to the LBC1921 study) and 1947 (to the LBC1936 study). Other SMS follow-up studies were conducted in Aberdeen, known as the Aberdeen Birth Cohort of 1921 (ABC1921) and 1936 (ABC1936) (Deary et al. 2009c; 2004b; Whalley et al. 2011).

This is an Open Access article, distributed under the terms of the Creative Commons Attribution licence (http://creative commons.org/licenses/by/4.0/), which permits unrestricted re-use, distribution, and reproduction in any medium, provided the original work is properly cited. 
The original aim of the LBC studies was to seek the determinants of normal (non-pathological) cognitive ageing from childhood to older age; they were extended to study cognitive and brain ageing within older age. Both cohorts are richly phenotyped, with many data types in common: socio-demographic, medical, cognitive (including the same test as at age 11), magnetic resonance imaging (MRI), carotid ultrasound, retinal imaging, blood biomarkers, physical function and fitness, genetic and epigenetic, lifestyle, psychosocial, personality, and many others (see Supplementary tables 1 and 2). The LBC1921 study has completed five waves of testing since baseline ( $n$ $=550$, mean age 79 years); most recently 54 participants were tested at age 92. No further testing of this cohort is planned. The LBC1936 study has completed four waves of testing since baseline $(n=1091$, mean age 70 years); most recently 550 participants were tested at age 79 . A fifth wave of data collection is planned to begin in the second half of 2017. Follow-up assessments for both cohorts were conducted at $~ 3$-yearly intervals. For further details, see the cohort profile paper (Deary et al. 2012a) and the LBC studies website (http://www.lothianbirthco hort.ed.ac.uk/). Detailed structural brain MRI was performed at mean ages 73, 76, 79 in the LBC1936 (Wardlaw et al. 2011), and at age 90 in the LBC1921.

This overview summarises key results from among the 300+ LBC1921 and LBC1936 peer-reviewed publications, focussing on those addressing cognitive and brain ageing, and placing these findings within the context of the wider, relevant literature. Among the key ageing-relevant factors considered here will be genetic, social, health, biomedical and lifestyles. We introduce the concept of marginal gains to encapsulate the probably many small influences that appear to contribute to differences in people's brain and cognitive health in older age. The marginal gains idea is often applied to performance in elite sports and business. However, based on the work reviewed here, we suggest that the idea could provide a useful framework for understanding and promoting the process by which a possibly large range of potentially malleable risk and protective factors (each of which might show a small association) may lead to an aggregate benefit for cognitive and brain ageing in later life. We stress strongly, though, that the LBC studies are observational and not intervention studies.

\section{Stability and change in intelligence}

If we wish to understand the contributions to people's cognitive differences in older age, then arguably the first question one should ask is how much of the cognitive variation in older age is due to long-standing cognitive trait differences. The LBC studies showed that the biggest factor in explaining why people's cognitive skills differ in older age is childhood intelligence differences. When the same validated intelligence test (MHT) is administered at age 11 years and again to individuals when they are in their late 70s, the raw correlations are between 0.6 and 0.7 (Deary et al. 2004b) and are still above 0.5 when the individuals are in their late 80s (Gow et al. 2011) and into their 90s (Deary et al. 2013). Furthermore, MHT intelligence scores in childhood and older age correlate significantly with scores on well-validated cognitive tests, even at the age of 90 (Deary et al. 2013). These correlations imply that about half or more of the variance in intelligence is stable across most of the human life course (see Deary, 2014). The cohorts also provide clear evidence that change in a general cognitive factor accounts for $\sim 50 \%$ of the variance in age-related changes across multiple cognitive domains (see Tucker-Drob et al. 2014; Ritchie et al. 2016).

These results show that individuals who are cognitively more able in youth show a tendency to still show a higher level of cognitive function in older age (Deary et al. 2004b; Royle et al. 2013). But what about the rate of change in cognitive ageing? That is, in the field of cognitive ageing, it is often asked whether 'ageing is kinder to the initially more able' (Deary et al. 1999; Gow et al. 2012c). The results are mixed. Some suggest that those with a higher early-life cognitive ability decline in cognitive functioning at a slower rate in later life (Bourne et al. 2007), whereas others report no association (Gow et al. 2008, 2012c). In the LBC1936, those with higher childhood ability tended to decline more with age in visuospatial ability, but there was no statistically significant association with any of the other cognitive measures (Ritchie et al. 2016). Overall, results from the LBC studies suggest that cognitive ability in early life, although it has a strong association with cognitive level in older age, does not confer an advantage with respect to cognitive ageing trajectory (Gow et al. 2011; Ritchie et al. 2016).

Knowing the long-term stability of individual differences in cognitive abilities is a valuable found ation for estimating which factors account for the other variance in cognitive function in older age. Therefore, if about $50 \%$ of the variance in cognitive function in older age is traceable back to childhood, we should seek reliable sources of the other $50 \%$, some of which will, of course, be measurement error. The non-error sources will probably include factors that are outside of our immediate and practical control, and those that might be amenable to change.

\section{Brain correlates of cognitive ageing}

Evidence derived from brain imaging studies of the LBCs (Wardlaw et al. 2011) supports a lifelong 'trait' 
of intelligence and its association with brain structure. In the LBC1936, intelligence at age 11 not only predicts cortical thickness in later life but accounts for over two-thirds of the cross-sectional association between cognitive ability and cortical thickness in later life. Adjusting for MHT scores at age 11 attenuates this association to non-significance (Karama et al. 2014). Individuals from the LBC studies who showed less relative decline in cognitive function between age 11 and later life also show better white matter microstructure (Deary et al. 2006a; Penke et al. 2012b), fewer white matter hyperintensities (WMH) (Valdés Hernández et al. 2013), slower progression of WMH (Ritchie et al. $2015 c, d)$, less brain atrophy and a larger intra-cranial volume (Royle et al. 2013), a bigger brain (Shenkin et al. 2009c), less small vessel disease (Staals et al. 2015), and fewer iron deposits (Penke et al. 2012a; Valdés Hernández et al. 2015b). Individuals with better cognitive abilities at age 73 showed less brain volume loss and less WMH growth over a 3-year follow-up period (Ritchie et al. 2015a). Coupled changes in white matter microstructure and fluid intelligence are consistent with a longitudinal link between brain 'disconnection' and cognitive ageing. The brain correlates of better cognitive ageing point to less shrinkage of the brain tissue generally, better white matter connections in the brain, and fewer hyperintensities in the brain's white matter (Ritchie et al. 2015c, d), and confirm that neuroimaging biomarkers are informative about cognitive changes. The state of the brain's structure in older age has significance beyond cognitive functioning; the LBC1936 study showed that older brain age (the deviation of the brain's structure from that expected for a given chronological age) is associated with earlier death (Cole et al. 2017).

The determinants of brain changes from age 73 to 76 have been investigated in the LBC1936. Relatively greater deterioration in MRI measures of brain macro and microstructure was associated with lower physical fitness and possession of APOE e4. Though other potential risk and protective (physical, health, cognitive, allostatic and genetic) variables were associated with baseline brain structure, they did not predict subsequent brain change over the short (3-year) follow-up period (Ritchie et al. 2017).

\section{Genetic influences on cognitive level and cognitive change}

In adulthood, twin studies estimate that between 50\% and $80 \%$ of the variation in general cognitive function is caused by genetic differences (Deary et al. 2009b). The LBC studies contributed to a consortium that was the first to use single-nucleotide polymorphism (SNP) data to estimate the SNP-based heritability of individual differences in human intelligence (Davies et al. 2011), which was subsequently expanded (Davies et al. 2015). The current estimate is that common SNPs in many genes, each having a very small effect, account for about $30 \%$ of the variation in human intelligence differences. This largely refers to contributions to the stable trait of human general intelligence. The emerging view of genetic influences on intelligence, confirmed by work on the cohorts, is that it is likely that a very large number of genetic variants have small effects (Deary et al. 2010; Plomin \& Deary, 2015).

The LBC studies contributed to a study in which common genetic variants (SNPs) were estimated to account for about $24 \%$ (but with a relatively large standard error) of the variability in lifetime cognitive change, i.e. from childhood to older age (Deary et al. $2012 b$ ). The same study found that the genetic factors contributed the majority influence on the lifetime stability of intelligence. Within that contribution, various candidate genes have been tested. However, other than possession of the 'risk' APOE e4 allele, which explains around $1-2 \%$ of the variance in cognitive change from youth to older age and within older age (Deary et al. 2002, 2004a; Luciano et al. 2009a, b; Schiepers et al. 2012; Ritchie et al. 2016; also see Daviglus et al. 2010) and is associated with age-related brain structural changes (Ritchie et al. 2017), no other candidate genes have been consistently linked to variation in cognitive function or with age-related cognitive decline (Visscher et al. 2003; Deary et al. 2005b; Kachiwala et al. 2005; Houlihan et al. 2009; Marioni et al. 2014b).

A different approach is to ask whether people's polygenic risk for disorders related to cognitive decline contribute to cognitive change, even in individuals without the disorders. In the cohort studies, increased polygenic risk of certain diseases, such as coronary artery disease (Hagenaars et al. 2016), ischaemic stroke (Harris et al. 2016a) and schizophrenia (McIntosh et al. 2013), is associated with lower cognitive ability, and greater relative cognitive decline in the case of polygenic risk for schizophrenia (McIntosh et al. 2013). Lower cognitive ability in older age was not associated with polygenic risk for diabetes (Luciano et al. 2014) or Alzheimer's disease (Lyall et al. 2013a, b, 2014; Harris et al. 2014). DNA methylation, which can be used to form an epigenetic biomarker of age acceleration, was associated with cognitive function in the LBC1936, but not cognitive decline over 3 years within old age (Marioni et al. 2015a). Apart from cognitive function, the LBC studies showed that a faster running epigenetic clock is associated with earlier death (Marioni et al. 2015b).

Thus, the LBC studies contribute to evidence that intelligence level from adolescence to older age is 
highly heritable and highly polygenic, and is substantially stable over time, with genetic factors contributing much to the lifetime stability. The existence of some genetic contributions to lifetime cognitive change does not mean that these are not amenable to intervention; with a greater understanding of genes' systems and gene expression pathways (e.g. Johnson et al. 2016), genetic contributions might well be modifiable. Establishing the heritability of intelligence and the genetic contributions to cognitive change is important for many reasons, not least because it also helps to elucidate the extent to which environmental influences contribute to lifetime cognitive change.

\section{Early-life and demographic factors}

Positive early-life factors, including birth parameters (Shenkin et al. 2001, 2004; Grove et al. 2017), education (Stern, 2002; Banks \& Mazzonna, 2012; Clouston et al. 2012; Ritchie et al. 2016), and childhood environment (Johnson et al. 2010; Ritchie et al. 2016), appear to have modest associations with better cognitive capacities in later life and better brain health according to only some MRI indices (Shenkin et al. 2009a; Cox et al. 2016; Field et al. 2016). However, we have not found evidence that early-life factors offer protection against cognitive decline in the LBCs or other studies (Shenkin et al. 2009b; Tucker-Drob et al. 2009; Zahodne et al. 2011; Gottesman et al. 2014; Ritchie et al. 2016). That is, they might be associated with long-standing cognitive level, but possibly not with cognitive trajectory.

Education is hypothesised to boost so-called cognitive reserve (Tucker \& Stern, 2011). However, we acknowledge that some users of this term make it ambiguous, because sometimes it refers to higher premorbid cognitive level, and sometimes to less steep decline. Longer schooling in the LBC1936 was a significant predictor of higher scores on a latent general cognitive factor at age 70, independently of childhood IQ score (Ritchie et al. 2016), and of greater cross-sectional cortical thickness in areas linked to the flexible integration of semantic knowledge (but not to other brain MRI markers; Cox et al. 2016). However, there was no evidence of an association between education and a latent factor of cognitive change from age 70 to 76 (Ritchie et al. 2015b, 2016). Though more education associates with better general cognitive abilities in later life, it appears, after adjustment for childhood intelligence, to be associated with some specific cognitive skills (Ritchie et al. 2015b), and does not appear to improve more fundamental aspects of cognitive processing, such as reaction time and inspection time (Ritchie et al. 2013). Education's effects might therefore be limited to specific aspects of intelligence tests, such as knowledge and perhaps reasoning, rather than a general factor of intelligence, and might offer no protection against cognitive decline (Ritchie et al. 2015b).

Some established correlates of lower intelligence test scores in youth, including low parental socio-economic status (SES), poor maternal nutrition, maternal smoking, and poor perinatal nutrition, are related to maternal intelligence, suggesting that these associations might in part be accounted for by the genetic link between mother and child (Shenkin et al. 2004; Deary et al. 2005a; Räikkönen et al. 2009). Indeed, parents pass on genetic variants associated with both intelligence and aspects of the socio-economic environment to their children (Deary et al. 2010; Marioni et al. 2014a; Hill et al. 2016). Yet, though social background (parental or environmental circumstances) may provide opportunities for educational and occupational attainment, results from the LBC studies suggest that childhood SES alone does not appear to have strong associations with cognitive decline in later life (Johnson et al. 2010; Ritchie et al. 2016). It may be that the choices that individuals make (personal life history variables), rather than early-life social milieu, have the greatest effects on cognitive abilities in later life (Johnson et al. 2010). Not only is childhood intelligence the strongest direct contributor to later life intelligence, it may contribute directly to one's ability to obtain education, and a safe and well-remunerated job, the typical indicators of SES (Deary et al. 2005c).

Consistent with the 'use it or lose it' hypothesis, researchers often ask whether a more intellectually demanding job in adulthood contributes to better cognitive function (Hultsch et al. 1999). Occupational complexity was associated with better cognitive performance in the LBC1936 at age 70 (after adjusting for age $11 \mathrm{IQ}$, education and social deprivation), accounting for $1-2 \%$ of the variance (Smart et al. 2014). Gender differences identified in the 1936 cohort, in relative IQ change between youth and age 70 (with an effect size of 0.19) favouring men (Johnson et al. 2011), an effect also reported in the LBC1921 (Deary et al. 2004b), might reflect men's greater involvement in the workforce in these samples and its potential to retard cognitive decline with age. However, not all studies report beneficial long-term effects of occupational characteristics on cognitive ageing (Finkel et al. 2009; Gow et al. 2014). More stimulating environments may help preserve cognitive ability in later life, but engagement in complex and intellectually stimulating activities may also be a consequence of individual differences in prior cognitive ability (Gow et al. 2012b); a dynamic longitudinal association seems likely.

\section{Lifestyle and psychosocial factors}

A number of factors potentially under an individual's control might improve cognitive ageing prospects 
and reduce the risk of cognitive decline and impairment (Lee et al. 2010; Baumgart et al. 2015). The LBC team have been investigating what these factors are and estimating the size of their effects. We preface this by stating that effect sizes are typically small, and so, like many potential behavioural changes for health, they would possibly have a detectable effect at population level rather than a manifest result for any individual.

\section{Smoking}

It is well documented that smoking is a risk factor for cognitive decline and dementia (Anstey et al. 2007; Peters et al. 2008). Evidence for past smoking is less consistent (Daviglus et al. 2010). In the LBC1936, those still smoking at the age of 70 performed more poorly than ex- and never-smokers on most of the concurrently performed cognitive tasks (Corley et al. 2012). Cigarette smoking in older age was found to be associated with slightly lower scores in general cognitive abilities and in speed of information processing, accounting for $0.7 \%$ and $0.6 \%$ of the variance, respectively. Past smoking was not associated with significantly poorer performance when compared with never-smokers in any cognitive domain. Lower childhood IQ predicted more likely onset and less likely cessation of smoking in the LBC1936. In the LBC1921 at age 80, current smokers had significantly lower MHT scores in older age than never- and ex-smokers after adjusting for childhood IQ (Deary et al. 2003; Starr et al. 2007). A lower childhood IQ predicted cessation but not uptake of smoking, perhaps reflecting social attitudes to tobacco over this particular historical period (Taylor et al. 2003).

Our results suggest that cessation of smoking in adulthood may 'buffer' the cognitive ageing experienced by those who continue to smoke, perhaps via decreased progression of WMH volume (Dickie et al. 2016), or decreased cortical thinning (Karama et al. 2015). When accounting for the amount of lifetime smoking, Karama et al. found that the cortex of subjects who stopped smoking appeared to have partially 'recovered' (the study was cross-sectional, so this was inferred) for each year without smoking. Although complete cortical recovery in affected areas was estimated to take on average 25 years in this sample, these important findings suggest that partial recovery is possible. In terms of public health implications, findings which hint at underlying neurobiological mechanisms such as these are valuable. Here we suggest that there might be both cognitive and cerebral benefits to quitting smoking, in addition to the better known health benefits, even for older adults who have been smoking for many years.

\section{Physical activity}

A higher level of participation in physical activity in later life was associated with better general cognitive abilities and processing speed in the LBC1936 at baseline, accounting for $0.7 \%$ and $1 \%$ of the variance, respectively (Gow et al. 2012b), and less cognitive decline over 11 years of follow-up (from age 79 to 90) in the LBC1921 (Gow et al. 2017). The lack of association between a cumulative activity score (spanning the ages of 20-75) and cognitive ability indicates, there may be specific periods in which engagement in physical activities may be particularly beneficial. Our findings of better cognitive functioning with greater physical engagement supports the wider evidence that physical activity has a significant role in determining healthy cognitive ageing (Lee et al. 2010; Blondell et al. 2014; Carvalho et al. 2014; McKee \& Schüz, 2015). Other studies have demonstrated that even mild activities, such as walking, were found to be protective in later life (Weuve et al. 2004). The results of a meta-analysis of prospective studies suggest that all levels of physical activity offer significant and consistent protection against cognitive decline (Sofi et al. 2011). Yet, despite this promise, randomised controlled trials of physical activity are equivocal; some report positive effects on cognitive function (Lautenschlager et al. 2008), whereas others find no improvements in global or even domain-specific cognitive abilities (Sink et al. 2015). However, a meta-analysis of 29 studies reported modest improvements in attention, processing speed, executive function and memory, with exercise training among non-demented adults (Smith et al. 2010). Type and intensity of exercise may be a factor; aerobic training programmes in older people lead to significant improvements not observed in those doing strength and flexibility exercises or in controls (see Bherer et al. 2013), suggesting a role for cardiorespiratory fitness in healthy cognitive ageing.

The biological mechanisms by which cognitive function might be enhanced through physical exercise training remain to be completely elucidated. Physical exercise in later life may exert a cognitively protective effect via preservation of brain microstructural integrity; more physical activity at age 73 was associated with less brain atrophy and fewer white matter lesions in the LBC1936 (Gow et al. 2012a). Associations with higher fractional anisotropy and higher normalappearing white matter volume became nonsignificant in the fully adjusted model. Another study showed that exercise training increases hippocampal volume and improves memory (Erickson et al. 2011). These results, and others (Marks et al. 2007; Voss et al. 2013; Tian et al. 2014), offer evidence for 
neurotrophic effects of physical activity on brain structure. Exercise may, of course, enhance cognition indirectly by improving psychological wellbeing (Herring et al. 2012a, b), improving sleep quality and minimising pain (Reid et al. 2010), all of which may secondarily impact neurocognitive functioning (Reppermund et al. 2011). It remains to be seen whether these factors in fact mediate any positive effects that exercise has on cognitive and brain health.

\section{Alcohol}

Findings on the association between alcohol use and cognition were less clear, consistent with other research (Daviglus et al. 2010). In the LBC1936, a higher intake of alcohol, particularly of wine, was associated with better memory function at age 70 after adjusting for age $11 \mathrm{IQ}$, accounting for around $1 \%$ of the variance in scores (Corley et al. 2011). An almost exclusive preference for wine among women alluded to a potentially beneficial effect of wine or of its components. However, memory performance was better in men with a higher overall alcohol intake and not necessarily due to wine intake per se. In the same sample, the use of Mendelian randomisation demonstrated that individuals with a higher genetic ability to process alcohol showed relative improvements in cognitive ability with more consumption, whereas those with low processing capacity showed a negative relationship between cognitive change and alcohol consumption with more consumption (Ritchie et al. 2014). This study indicates that any protective effects of alcohol consumption on cognitive change may be contingent on an individual's genetically influenced capacity to metabolise alcohol.

\section{Diet and nutrition}

Certain dietary components (Loef \& Walach, 2012; Morris, 2012) and dietary patterns (Féart et al. 2010; Tangney et al. 2011; Allès et al. 2012) have been linked with better cognitive ageing in the literature, yet the results from the LBC studies have been mixed. In the LBC1936, the proportion of total variance in cognitive function at age 70 years accounted for by the age 70-reported intake of the nutrients B2, B12, folate, vitamin C was $<1 \%$ (McNeill et al. 2011). In the same study, supplement use was associated with better cognitive function, but this was accounted for by a higher IQ in youth. Individuals adhering to a Mediterranean-type dietary pattern (Corley et al. 2013) and consuming a greater intake of dietary flavonoids (Butchart et al. 2011) and more caffeine (Corley et al. 2010b) had better cognitive skills at age 70, but these associations largely disappeared upon adjustment for cognitive ability in youth. Individuals with a higher intake of these dietary components were more likely to have a higher IQ in both childhood and old age. In the same sample, those with a higher Mediterranean diet index score showed less total brain atrophy over a 3-year period (Luciano et al. 2017). However, the effect size was small $(0.5 \%)$ and not corrected for multiple comparisons, and so replication studies are needed. In other analyses, healthy (nutrientdense) dietary patterns were associated with significantly lower levels of circulating inflammatory markers (Corley et al. 2015). Given that chronic low-grade inflammation is a putative predictor of cognitive decline, a relationship between diet and cognitive decline via pro-inflammatory processes may be a promising avenue for future research. Dietary intake of iron was assessed in relation to brain ageing in the LBC1936, since brain iron accumulation is involved in neurodegenerative diseases. However, neither iron nor calorie or dietary cholesterol intake, at the levels found in normal western diets, was directly associated with iron deposition load assessed on structural MRI scans (Valdés Hernández et al. 2015a). It appears that at least some aspects of diet that are associated with cognitive function in older age are confounded with prior cognitive ability, and probably the lifestyle changes associated with cognitive differences.

Dietary assessment was not included in the LBC1921 study, but lower serum B12 at age 79 was associated with greater cognitive decline between ages 11 and 79. By contrast, serum folate at age 79 correlated with age $11 \mathrm{IQ}$, and controlling for this reduced the correlation with IQ in old age to almost zero (Starr et al. 2005).

\section{Intellectual activity}

Performing socio-intellectual activities (examined using a latent factor) was no longer associated with general cognitive ability, processing speed or memory in the LBC1936, following adjustment for childhood IQ (Gow et al. 2012b). Intellectual activities were not associated with any of the structural brain parameters assessed (Gow et al. 2012a). However, we reported a positive effect of being bilingual on later-life cognition, even in those who acquired their second language in adulthood (Bak et al. 2014). These effects could not be explained by other variables, such as childhood IQ, SES, immigration or gender. Early $v$. late acquisition showed differential effects, depending on childhood IQ. Overall, individuals with higher intelligence seem to benefit more from early acquisition and those with low intelligence from late acquisition, but neither group showed negative effects. Furthermore, learning a second language was related to better conflict processing, irrespective of initial childhood ability or social class (Cox et al. 2016). 


\section{Social factors and psychological wellbeing}

In analyses including social networks, social support and loneliness, loneliness was the only factor which contributed to the prediction of poorer old age cognitive abilities, explaining about $2 \%$ of the variance at age 79 in the LBC1921 (Gow et al. 2007). In the LBC1936, less loneliness, more social support and shared living arrangements were most consistently associated with aspects of cognitive ability, though these associations appeared to be partly accounted for by fewer symptoms of depression (Gow et al. $2013 a$ ). In the same sample, lower levels of anxiety were associated with more favourable relative change in cognitive function between ages 11 and 70 (Johnson et al. 2010). However, a large multicohort study (including the LBC1921) of mental wellbeing in relation to cognitive function found that associations in older people are small and may be confounded by personality trait differences (Gale et al. 2012).

\section{Health}

Intelligence in youth and older age is associated with important health outcomes (Deary et al. 2010), and age-related disease increases the risk of cognitive decline (Deary et al. 2009a). An individual's cognitive trajectory is the result of a combination of shared influences with the rest of the body. However, some health conditions are modifiable via lifestyle changes and medication.

\section{Physical fitness}

In the LBC1921, grip strength and reasoning were correlated at each wave of testing in the ninth decade, but their trajectories of decline were not (Deary et al. 2011). A latent trait of physical fitness - derived from lung function, grip strength and walking speed - accounted for over $3 \%$ of the variance in cognitive change between ages 11 and 79 years in the LBC1921, after adjusting for childhood IQ (Deary et al. 2006b). The same physical fitness trait was associated with better 6-year cognitive change in the LBC1936, yet when physical measures were assessed individually, they showed few associations (Ritchie et al. 2016). Declining physical fitness over a 3-year period was associated with less brain volume at baseline in the LBC1936 sample, and did not diminish when covarying for education, social class, and health status (Aribisala et al. 2013), and longitudinally with age-related changes in brain structure (Ritchie et al. 2017). These results suggest that higher general fitness is protective against cognitive decline and brain ageing; this is important given that it is potentially modifiable.

\section{Cardiovascular risk factors}

The LBC studies have shown us that people's vascular health in later life are in part associated with early-life intelligence in addition to being associated with age-related cognitive change (McGurn et al. 2008). In the LBC cohorts, lifestyle-related risk factors for cardiovascular disease (CVD) - diabetes, low high-density lipoprotein (HDL) cholesterol, and being overweight/ obese - were (independently) associated with poorer cognitive function at age 70 , but statistical significance was lost following adjustment for age 11 IQ in each of these analyses (Corley et al. 2010a, 2015; Mõttus et al. 2013; Aslan et al. 2015).

A higher childhood IQ was found to predict lower hypertension in adulthood in a sample comprising the LBC1921 and MIDSPAN study such that there was a $3.15 \mathrm{mmHg}$ decrease in systolic blood pressure and a $1.5 \mathrm{mmHg}$ decrease in diastolic blood pressure for each standard deviation increase in childhood IQ (Starr et al. 2004b). However, individual differences in childhood IQ only partly accounted for the association between hypertension and lower adult cognitive function, suggesting that lifestyle factors have a part to play. Lower ankle-brachial index, a frequently used measure of generalised atherosclerosis, was associated with worse cognitive performance in older age, independently of prior cognitive ability, especially in the oldest old (>85 years), possibly because of long-term exposure to atherosclerotic disease (Laukka et al. 2014). Multivariate analyses of the LBC1936 data suggest that diagnoses of CVD, hypertension or diabetes are not uniquely associated with cognitive performance (with the small exception of CVD and slower processing speed), or with cognitive decline, beyond the other predictors in the model (Tucker-Drob et al. 2014). Following adjustment for age 11 IQ, Ritchie et al. (2016) reported that the associations between CVD history and cognitive level in later life were attenuated by $90 \%$.

In contrast, brain MRI studies in the LBC1936 indicate a small negative association between vascular risk factors (VRFs) and brain health, independently of prior ability. VRFs combined explained $1.4-2 \%$ of WMH variance, of which hypertension explained the most (Wardlaw et al. 2014). A lower HDL cholesterol level (Dickie et al. 2016) and poorer glycaemic control (in those who carry the APOE risk e4 allele) (Cox et al. 2017), were identified as important independent CVD risk predictors for the progression of WMH from age 73 to 76 . Hypertension is associated with increased $\mathrm{WMH}$ but research carried out by the LBC team has indicated that they may be associated indirectly, via increased arterial stiffness (Aribisala et al. 2014). 
The current prevailing view is that VRFs are potential aetiological factors for cognitive decline but that the association is age-dependent. For some VRFs, such as obesity, hypertension and hypercholesterolaemia, it is mid-life levels that seem to be more important than those measured at older ages for cognitive outcomes (Ballard et al. 2011; Qiu \& Fratiglioni, 2015). Many clinical trials and epidemiological studies, including the LBCs, have been conducted among older adults $>65$ years when VRFs probably no longer act as risk factors and might be more likely to be modified by age-related concomitant disease.

\section{Medications}

Taking a greater number of medications is associated with a relative worsening of cognitive function from childhood to old age, explaining about $2.2 \%$ of the variance in cognitive change in the LBC1921 (Starr et al. 2004a). The total number of medications prescribed is a proxy indicator of disease burden, and, therefore, it is unclear whether it is the drugs themselves or the underlying disease for which they are prescribed that is causing the relative decline in IQ. In the same sample, however, taking statins, as indicated for CVD, was associated with a relative improvement in cognitive change across the life span, explaining about $2.8 \%$ of the variance (Starr et al. 2004a). Statin users in both LBC cohorts had lower childhood IQs, but the cross-sectional associations with cognitive function at age 70 in the LBC1936 were not robust in the final models, which adjusted for total cholesterol levels (Corley et al. 2015). In other literature, there is no consistent epidemiological evidence that exists for an association of cognitive decline with statins, anti-hypertensive medications or anti-inflammatory drugs (Daviglus et al. 2010).

\section{Health literacy}

Health literacy was related, in the LBC1936, to childhood IQ and to IQ change from age 11 to 70, independently of SES, education, personality, and with worse general fitness, greater body mass index (BMI) and fewer natural teeth (Murray et al. 2011; Mõttus et al. 2014). Both studies found that health literacy is related to general (not health-specific) cognitive differences, and therefore raise the possibility that 'health literacy' measures are little more than cognitive ability measures. The results of Mõttus et al. suggest that health literacy measures do not add additional variance to the already present cognitive-health associations. Lifelong health may be associated with health literacy via the effect of general cognitive abilities on health knowledge and health management, of the sort an individual may require when diagnosed with an illness.

\section{Biomedical factors}

\section{Allostatic load (AL)}

$\mathrm{AL}$ has been proposed as a general framework for understanding the cumulative effects of life stress on individuals. Greater AL, which we and others have tried to capture as a compendium measure of a range of inflammatory, cardiovascular, and metabolic measures (e.g. Booth et al. 2013b), was associated in LBC1936 with poorer general cognitive ability, processing speed and knowledge, but not memory or nonverbal reasoning, and with brain volume measures (especially lower white matter volume) (Booth et al. 2015). The associations of AL with cognitive abilities were not mediated by the brain volume measures. AL at age 73 was associated with IQ scores at age 11 but did not predict cognitive change from age 11 to 73. In this first study to consider AL, cognitive ability and neuroimaging measures of brain volume, the results suggest that the cumulative wear and tear on the body from a lifetime of stress responsivity is associated with both brain structure and cognitive ability in early- and later life but not with cognitive change from childhood to the early 70 s.

Elevated levels of salivary cortisol (often considered an important component of $\mathrm{AL}$ ) were related in a subsample of the LBC1936 to poorer lifetime cognitive change, but only for levels taken in response to a mild psychological stressor, and not for diurnal levels (Cox et al. 2015a, b, 2017). This effect was significantly mediated via poorer white matter microstructure, but was unrelated to differences in hippocampal volume or shape.

A potential contributor to $\mathrm{AL}$ is infection from the cytomegalovirus (CMV). The LBC team reported that significant inverse CMV infection and cognitive ability associations were confounded by early-life cognitive, demographic and environmental factors (Gow et al. 2013b). In those who were CMV-infected, however, higher CMV antibody level was significantly associated with lower general cognitive ability and processing speed, accounting for around $1-2 \%$ of the variance, even after controlling for potential confounds. This indicates a potentially detrimental effect (via lifelong wear and tear) of increased antibody response rather than CMV infection per se.

\section{Other biomedical factors}

Few other biomedical factors examined in the cohorts have yielded robust associations with cognitive ageing. Research covering inflammation (Luciano et al. 2009c; Aribisala et al. 2014), thyroid function (Booth et al. 2013a), renal function (Munang et al. 2007), telomere length (Harris et al. 2006, 2012, 2016b), and retinal 
blood vessel parameters (Patton et al. 2007; Henderson et al. 2011; Laude et al. 2013; McGrory et al. 2016) all show weak-to-null associations with the level and change of cognitive domains or a variety of brain measures. Of those that were initially significant, many became non-significant or were markedly attenuated following adjustment for childhood IQ scores, i.e. they are examples of confounding or reverse causation. The association between inflammatory markers (particularly fibrinogen) and processing speed was an exception; significance was maintained in the presence of childhood IQ and/or CVD risk factor adjustments. This might reflect variation in physiological integrity (Luciano et al. 2009c). However, inflammatory processes, long implicated in cognitive decline and the development of mild cognitive impairment (MCI) and dementia, were only weakly associated with markers of cerebral small vessel disease (Aribisala et al. 2014).

\section{Genetics and environment: a lifelong interaction}

Accepting the importance of both genetic and environmental contributions to people's differences in cognitive ageing acknowledges their interplay across the life course and constitutes a new challenge for future research. Indeed, there is moderate-to-strong heritability of lifestyle factors that is stable over age (McGue et al. 2014), unsurprising, given that most behavioural characteristics are (partly) inherited. However, genetic influences can be modified by physiological and environmental influences, and these may play a larger role in the expression of cognitive impairments (Mortimer et al. 2005; Stern, 2012). Alcohol (Ritchie et al. 2014) and glycaemic control (Cox et al. 2017) have been highlighted here as potential targets for mitigating cognitive and brain ageing in those who fall into a risk group with a greater genetic predisposition towards such deleterious effects. Heritability should not be erroneously interpreted as evidence for unalterable genetic determination of behaviour. An illustration of the variable determinacy of genetic factors was the LBC1936 study in which polygenic scores for type 2 diabetes were more strongly associated with glycated haemoglobin in those with lower childhood IQ scores when compared with higher IQ scorers (Mõttus et al. 2015). Behavioural change may be challenging, but it is possible either by individuals or by clinicians, as part of a delivered health-care intervention.

\section{A multivariate approach to cognitive and brain ageing}

Many of the studies reported above, take in essence, a univariate approach; that is, given that they do have some appropriate covariates, they focus mostly on a single potential determinant of cognitive level or change. Of course, some of these potential determinants will themselves be associated, and so we cannot simply make a list of determinants and assume they will have additive associations. Therefore, the LBC studies have recently taken a more complex multivariate approach in which important predictors were modelled simultaneously on cognitive level (age 70) and change (between ages 70 and 76 in LBC1936) using latent growth curve models (Ritchie et al. 2016). In these analyses, univariate correlates of age 70 cognitive ability level (at the same time measuring lifetime cognitive change from age 11 to age 70) were many; those individuals with better general cognitive function at age 70 were younger when tested, had higher childhood intelligence, were more educated, were from more professional occupational classes, lived in more affluent areas, were fitter (on all three performance indicators), had lower BMI, were less likely to smoke, and were less likely to have cardio-metabolic illness. Carriers of the APOE e4 allele also performed less well on the visuospatial and speed domains. Following multivariate adjustment, however, only age, sex (female), higher age $11 \mathrm{IQ}$, more education, and better forced expiratory volume remained significant correlates of better general cognitive ability level. Importantly, none of the social or health variables remained significantly associated with cognitive ability level when modelled together with other covariates (and correcting for multiple comparisons).

Likewise, few predictors of less cognitive decline between the ages 70 and 76 in LBC1936 survived multivariate modelling, with the exception of $A P O E$ e4 non-carrier status, sex (female) and better grip strength. The predictors included in these analyses together accounted for $80.5 \%$ of the variance in cognitive level, and $16.1 \%$ of the variance in general cognitive decline.

Predictors of longitudinal changes in brain structure have rarely been examined using multiple heterogeneous variables simultaneously. In a recent multivariate investigation of neurostructural changes in the LBC1936 (Ritchie et al. 2017), many variables significantly correlated with baseline (age 73) brain structure, but few could account for significant heterogeneity in subsequent brain change (between 73 and 76). Better physical fitness and $A P O E$ e4 non-carrier status were the most consistent predictors of differential rates of brain ageing, though effect sizes were small. Education and prior intelligence were correlates of brain structure, but not related longitudinally to ageing-related changes in brain structure. The distinction between crosssectional and longitudinal analyses of brain ageing is important: in cross-sectional studies, it is not possible 
to differentiate between developmental processes that occur in earlier periods of life from effects that are specifically ageing-related (Tucker-Drob \& Salthouse, 2011). Subsequent waves of the LBC1936 will bring more occasions of brain imaging over longer periods, providing a larger target for our predictors of differential brain ageing.

Collectively, the LBC studies suggest that a number of environmental factors may have small associations with cognitive abilities in later life. It is likely that many of these factors covary. If there are multiple univariate predictors, and few that survive the multivariate model, then one possibility is that some might mediate others via testable pathways. To understand the data more fully requires techniques such as structural equation modelling, which can explicitly explore mediation effects, latent traits and multiple outcome variables; there are many examples of these in the LBC reports. Multivariate techniques - considering many predictors together - may provide a more realistic consideration of the predictors of cognitive and brain ageing.

\section{Discussion}

In this paper, we have described some of the follow-up studies of people who took part in the SMS of 1932 and 1947 , and given overviews of 100 LBC papers that pertain to cognitive ageing across the life course, and to brain ageing, in the context of some existing literature. Broadly, the LBC studies have found two things from the cognitive ability test scores at age 11 years: first, those with higher childhood intelligence tend to be healthier and more cognitively able in old age; second, that some people got to older age with better or worse cognitive function that one would predict given their ability at age 11 . Observations by the LBC studies over the past 15 or so years have helped to identify which candidate determinants are associated with these differences in lifetime cognitive resilience and brain and general health, across genetic, sociodemographic, health, and lifestyle domains.

Overall, the findings support the link suggested by Juvenal (first to second century AD) between a healthy body and a healthy mind. An older body, which is physiologically fitter and engages in regular physical activity, is associated with a higher childhood IQ score, tends to experience less cognitive change over the life course, and less cognitive decline and deleterious brain changes within old age. VRFs, such as smoking, hypertension and cholesterol, and greater cumulative AL, may have important associations with cortical thinning, brain white matter integrity, and brain atrophy in later life. All of this is in line with research, which provides evidence that the ageing brain retains a considerable functional plasticity which is very much dependent on the interaction of individuals with their environment (see Mora, 2013).

The multivariate results to emerge from work on the cohorts suggest that when many potential predictors are modelled simultaneously, only a subset of correlates of cognitive level and brain structure are predictive of differences in cognitive and brain ageing, at statistically significant levels (Ritchie et al. 2016; 2017). One possible reason for stronger results in the cross-sectional data is that determinants have had most of the life course to contribute to brain and cognitive variance. In the change analyses within older age, we report only 3-year change in MRI data, and 6-year change in cognitive markers. Even though it is during a period of time when change over time is greater, it is still hard reliably to detect very subtle changes over such a short period. Nonetheless, our findings are complementary to those of systematic reviews and meta-analyses (see Daviglus et al. 2010; Plassman et al. 2010), which report that few observational studies had sufficient evidence from which to draw conclusions about particular behavioural, social and economic factors, and their association with cognitive decline. Where there are few reports of significant associations with cognitive change, then interventions may be less likely to succeed. However, where there are more consistent significant associations with cognitive change, given that observational studies cannot address causality, then even this does not necessarily mean we have identified a target for intervention.

\section{Strengths and limitations}

As birth cohort samples (who share the same year of birth), there is a natural control for much of the confounding effects of chronological age. The LBCs are unusually well-phenotyped samples, which benefit from multiple later-life waves of follow-up. The use of multimodal neuroimaging in concert with these other data can help elucidate some potential underlying mechanisms. A major strength of these studies is the availability of cognitive data at distinct time points (age 11 and later life) creating a rare opportunity to distinguish factors that might have a true effect on later-life cognitive ability - possible causal factors - from the potentially confounded factors (i.e. confounded by childhood IQ). Ideally, the influence of premorbid cognitive ability on cognitive ability in later life is best assessed by using the earliest possible direct measure of cognitive ability to avoid the 'contamination' by lifestyle, adult SES, and health factors that may affect cognitive abilities, even by early adulthood. Childhood cognitive ability scores are rare in studies of cognitive ageing and shine fresh light on aspects rarely addressed by other observational investigations. 
The LBC studies have limitations. Given that our samples are self-selecting, they are biased towards high-functioning, well-educated, motivated volunteers, as is the case in many studies of cognitive ageing. Nonetheless, potential incipient cognitive impairment among participants, as yet clinically undetected, must be acknowledged. Although the LBC studies can measure relative cognitive change from childhood to older age, they have not documented the cognitive changes that occurred from childhood to early adulthood and from there to age 70 (LBC1936) or age 79 (LBC1921). It is possible that changes over these periods of the life course are associated more strongly with some of the proposed predictors. Some lifestyle behaviours including those that influence cardiovascular and metabolic risk may be most influential in midlife compared with late life (Kuh \& Cooper, 1992; Carlson et al. 2008; Lee et al. 2010; Rovio et al. 2010). A particularly salient example of this is cholesterol (van Vliet et al. 2009). Finally, due to the synergistic effect of lifestyle factors, the extent to which the apparent effects of one health behaviour is attributable to (i.e. confounded or mediated by) another is unclear. For example, other studies show that physical activity and exercise are increased by active social networks (Leroux et al. 2012), and that smokers tend to have poorer dietary choices than non-smokers (Woodward et al. 1994). The focus on single associates/interventions may underestimate the effect of multimodal or combined approaches.

\section{Confounding and reverse causation}

One of the most consistent observations to emerge from the LBC studies is that the apparent causes of cognitive ageing may not be causes at all. Some of the putative health and lifestyle determinants of cognitive ageing differences are themselves predicted by long-ago measured childhood differences in intelligence (Whalley et al. 2006; Deary et al. 2009a; Deary, 2010). Therefore, a cross-sectional association between a variable such as diet and cognitive ability in older age might - in part or whole - be the result of childhood IQ predicting both. Physical function and disease states may in part be acting as proxy markers of lower childhood IQ, and this might account for portions of the variance in cognitive ability years later. The repeated demonstration of confounding by prior ability across multiple areas in the LBC studies covering lifestyle, health and biomedical markers, and MRI indexes of brain health, is relevant to the debate on what is called 'differential preservation' $v$. 'preserved differentiation' (Salthouse, 2006; Bielak, 2010; Gow et al. 2012d; Bielak et al. 2014). Central to this theory is the critical question of whether certain factors alter the trajectory of age-related cognitive decline (differential preservation) or are associated with enhanced baseline cognitive ability (preserved differentiation). In searching for determinants of cognitive ageing, researchers aim to identify evidence of differential preservation. This important distinction highlights the need to design studies that will shed light on directionality when empirically feasible.

However, does childhood IQ represent a true causal link in some of the reported associations? One could argue that confounding by prior IQ does not necessarily rule out a protective or adverse effect of a predictor. Twin studies provide some reassurance for this (e.g. Crowe et al. 2003; Gatz et al. 2006). The role of lifetime IQ might, more realistically, be one of substantive causation; that is, higher IQ might have a direct impact on the uptake of healthy behaviours via better health literacy, better decision making, and a greater understanding of the consequences of one's behaviour. In essence, higher IQ individuals may be more likely to engage in a lifestyle that is protective against cognitive decline. With these theoretical considerations in mind, it seems most plausible that there is a dynamic cycle involving IQ, self-management of health, and ultimate cognitive outcomes.

Another possibility is that associations between candidate determinants and cognitive health may be caused by some third confounding variable or set of variables and may be the result of a more basic factor(s) affecting both the apparent cause and effect. Thus, many researchers are interested in whether there are general ageing effects, known as the 'common cause' theory of ageing that occur across cognitive and physical modalities attributable to core biological processes that deteriorate with age (Schaie, 2005). However, recent evidence from the LBC studies has cast doubt on this idea. Not only did physical functions appear to age separately, there was also no compelling evidence for coupled change across cognitive and physical functions in later life (Deary et al. 2011; Ritchie et al. 2016). Contrary to the 'common cause' hypothesis, these findings suggest multiple largely independent causes of ageing across bodily systems.

\section{Marginal gains: a modest multivariate recipe for healthy cognitive ageing}

From our LBC results overall, it seems likely that, other than intelligence scores from youth, a large number of genetic and other predictors have small associations with cognitive efficiency in later life. The most consistently cited factors linked to cognitive ability or ageing - smoking, physical activity, and variation in the APOE gene - have effect sizes of the same magnitude, often accounting for $1-2 \%$ or less of the variance in 
cognitive outcomes (Whalley et al. 2005; Deary et al. $2009 a, b)$. Though small in statistical terms, modifying some of such factors or their downstream effects could have substantial benefits at population levels. It is important to know what these effects are, so we can discover the combination of factors that might help people age better.

In terms of preserving mental abilities or delaying cognitive decline, the available evidence suggests that there is no magic bullet. Thus, the small effects we find, even if replicable and causal, might be useful at the population level, but are not necessarily good predictors at an individual level. Perhaps a helpful way of thinking about successful cognitive ageing can be gained from the theory of marginal gains, a concept that has become commonplace in the world of elite sport (see Clear, 2015, http://jamesclear.com/marginalgains). The principle behind the marginal gains idea is that if you improve in every variable (or lifestyle factor) underpinning or influencing your performance (in our case, cognitive abilities) by just $1 \%$ or so, then, cumulatively, you get a significant improvement, or an 'aggregate of marginal gains'. In terms of Team Sky (GB's professional cycling team), every aspect of cycling was decomposed and improved. A programme of small changes was implemented from addressing nutrition, to the ergonomics of the bike seat, clothing, bedding, sleeping position, and even handwashing techniques to prevent infections. Within 3 years, the team had won three Tour de France competitions and $70 \%$ of all track cycling gold medals at the 2012 Olympic Games.

Mutatis mutandis, an approach, which recognises the complexity of the factors influencing brain and cognitive health in later life might provide a useful framework for promoting healthy cognitive ageing. At an individual level, it encourages a proactive approach, in finding and exploiting small margins for improvement at every stage. Small changes, as suggested by marginal gains theory, may help individuals to overcome the perceived barriers to behaviour change (e.g. self-confidence and self-efficacy), which often prevent people from embarking on a new and often overwhelming regime. Clearly, some contributions to cognitive ageing are more open to interventions than others. Over time, whereas it may not be apparent, each small positive lifestyle change, such as going out for a walk every day, could add up to a significant advantage in terms of improving physical health (reducing risk of hypertension, dyslipidemia and metabolic syndrome, obesity), mental health (loneliness and social isolation, depression) and cognitive health, and this is likely to have a cumulative population-level effect. Tailoring interventions that take into account individual differences in risk genotypes might help to target an optimal set of gains. The 'magic' may lie in the accumulation of many such gains over time to put individuals, in elite sporting terms, 'ahead of the opposition'. Let us not fail to mention that 'marginal gains' would be a life-course approach; e.g. given that childhood cognitive ability accounts for about half of the variance in cognitive function in older age, then any effective boost to cognitive level in youth will be some insurance against descending to lower cognitive levels in older age.

\section{More to life than cognitive function}

Cognitive function is critical for mental and physical health. However, happiness and satisfaction with life are also key indices of successful ageing. Life satisfaction in the cohorts was unrelated to IQ in either childhood or late adulthood or to cognitive change over the intervening period. It may be that an individual's subjective wellbeing comes from having sufficient cognitive ability for the important aspects of one's life (Gow et al. 2005). Life satisfaction is also partly a result of personality factors, mood states (Brett et al. 2012), and social factors, such as having a strong social network (Gow et al. 2007). Although space prohibits more detailed discussion, some of our reports in the LBCs have focussed on health and happiness/wellbeing in older age, both quantitatively (Zammit et al. 2012, 2014) and qualitatively (Carpentieri et al. 2016, 2017; Lapsley et al. 2016).

\section{Conclusions}

People start off at different cognitive levels and vary in how much their cognitive functions change with age, even in those who do not have dementia or other neurodegenerative changes. The LBC studies suggest that cognitive and brain ageing are most likely the result of a multivariate accumulation of disparate influences. Potential risk and protective factors include contributions from genetic, medical, lifestyle and psychosocial domains (see Box 1). Identifying these factors is a key priority for research aiming to address the challenges associated with demographic ageing. Lifestyle factors can be promoted or discouraged, as appropriate, via interventions aimed at delaying, ameliorating or even reversing age-related cognitive decline. We must hope that even genetic contributions, linked to cognitive change and decline, have discoverable mechanisms which might afford interventions. But, whereas predictors of cognitive level in old age are numerous, predictors of cognitive decline's slope - that is, correlates of differential preservation - have, as yet, been few and far between, often with very small effect sizes.

Further longitudinal investigations of potentially malleable factors and cognitive decline in the LBC 
Box 1. Key points

- A Good Start - Intelligence differences in youth are the largest contributor to cognitive ability differences in older age.

- Stable Minds - Intelligence differences measured at age 11 are relatively stable across the life course, even into the ninth decade.

- Genetic Contributions - Common genetic variants account for about $24 \%$ of change in general cognitive ability between youth and old age. Variation in APOE is part of this.

- Few Clear Determinants of Change - There are multiple correlates of cognitive ability level in later life but as-yet few reliable genetic, lifestyle, health and psychosocial predictors of cognitive change.

- Clearest Results - The most consistently-cited lifestyle and health factors linked to brain and cognitive ability or cognitive ageing are smoking, physical activity and fitness, and allostatic load.

- Social Factors - Education and occupational complexity might also contribute to healthy cognitive ageing in terms of level but not of slope.

- Confounding/reverse causation - Some factors, such as body mass index, diet, and inflammation, are associated with cognitive function in older age but these associations largely disappear after adjusting for childhood IQ, implying that the latter might be a confounder that is associated to the supposed exposure.

- Cortical Disconnection - Declines in brain white matter microstructure are coupled with declines in cognitive ability in some, but not all, cognitive domains.

- Gene $\times$ Environment - Some people may be more predisposed to the possible negative cognitive effects of bio-behavioural factors (such as alcohol and poor glycaemic control).

- Marginal Gains - Successful cognitive and brain ageing is most probably achieved by optimising a number factors linked to brain and cognitive measures, which each only account for a small $\%$ of the variance.

- Last Cautions - These points are largely based on observational and not intervention studies, and also require independent replication.

are in progress, affording greater power, reliably to detect these subtle associations due to longer follow-up periods and a greater number of sampling points. We also continue to expand our information sources on the participants, which now includes whole-genome sequencing on almost all participants, DNA methylation testing on most participants on most waves, gene expression on LBC1936 at 70 and 76, post-mortem brain tissue (Henstridge et al. 2015), stem cells, lifetime addresses on LBC1936 to assess environmental exposures, and National Health Service medical records linkage.

Future research should continue to examine predictors of actual cognitive changes rather than simple levels of performance, because the latter are ambiguous with respect to the temporality and direction of causation. At the present time, in order to enhance one's chances of healthy cognitive ageing, the stronger cases may be made for being physically active and fit, keeping one's health in check (and keeping AL low), and avoiding smoking; and perhaps less strong cases may be also made for learning a new language, increasing one's social network, and eating healthy. Small and manageable improvements across a broad range of behaviours have potential for improving longterm cognitive and brain outcomes.

\section{Supplementary Material}

The supplementary material for this article can be found at https://doi.org/10.1017/S0033291717001489.

\section{Acknowledgements}

We thank the LBC1921 and LBC1936 participants. We also thank: the members of the LBC1921 and LBC1936 research team who collected and collated the data analysed; the other LBC study investigators and reports of the authors; the nurses, radiographers, and other staff at the Wellcome Trust Clinical Research Facility and the Brain Research Imaging Centre in Edinburgh; the staff at Lothian Health Board; and the staff at the Scottish Council for Research in Education (SCRE) Centre at the University of Glasgow. 
The Lothian Birth Cohort 1921 data collection was supported by the Biotechnology and Biological Sciences Research Council (BBSRC; 15/SAG09977) and by a Royal Society-Wolfson Award to author I.J.D. The LBC1936 is supported by Age UK (Disconnected Mind programme grant), which also supports author J.C. Brain imaging acquisition and analysis (which took place at the Brain Imaging Research Centre, University of Edinburgh) was supported by the Medical Research Council (MRC; G1001245, G0701120), which also supports author S.R.C. (MR/M013111/1). The work was undertaken by the University of Edinburgh Centre for Cognitive Ageing and Cognitive Epidemiology, part of the cross council Lifelong Health and Wellbeing Initiative (MR/K026992/1). Funding from the UK Biotechnology and Biological Sciences Research Council (BBSRC) and the UK Medical Research Council (MRC) is gratefully acknowledged.

\section{Declaration of Interest}

None.

\section{Ethical Standards}

The authors assert that all procedures contributing to this work comply with the ethical standards of the relevant national and institutional committees on human experimentation and with the Helsinki Declaration of 1975, as revised in 2008.

\section{References}

* = LBC study publication

$+=$ ABC study publication

$\ddagger=$ Scottish Mental Survey publication

Allès B, Samieri C, Féart C, Jutand MA, Laurin D,

Barberger-Gateau P (2012). Dietary patterns: a novel approach to examine the link between nutrition and cognitive function in older individuals. Nutrition Research Reviews 25, 207-222.

Anstey KJ, von Sanden C, Salim A, O'kearney R (2007). Smoking as a risk factor for dementia and cognitive decline: a meta-analysis of prospective studies. American Journal of Epidemiology 166, 367-378.

*Aribisala BS, Gow AJ, Bastin ME, Hernández MDCV, Murray C, Royle NA, Maniega SM, Starr JM, Deary IJ,

Wardlaw JM (2013). Associations between level and change in physical function and brain volumes. PLOS ONE 8, e80386.

*Aribisala BS, Morris Z, Eadie E, Thomas A, Gow A, Hernández MCV, Royle NA, Bastin ME, Starr JM, Deary IJ, Wardlaw JM (2014). Blood pressure, internal carotid artery flow parameters, and age-related white matter hyperintensities. Hypertension 63, 1011-1018.
*Aslan AK, Starr JM, Pattie A, Deary IJ (2015). Cognitive consequences of overweight and obesity in the ninth decade of life. Age and Ageing 44, 59-65.

*Bak TH, Nissan JJ, Allerhand MM, Deary IJ (2014). Does bilingualism influence cognitive aging? Annals of Neurology 75, 959-963.

Ballard C, Gauthier S, Corbett A, Brayne C, Aarsland D, Jones E (2011). Alzheimer's disease. Lancet 377, 1019-1031.

Banks J, Mazzonna F (2012). The effect of education on old age cognitive abilities: evidence from a regression discontinuity design. Economic Journal 122, 418-448.

Baumgart M, Snyder HM, Carrillo MC, Fazio S, Kim H, Johns H (2015). Summary of the evidence on modifiable risk factors for cognitive decline and dementia: a population-based perspective. Alzheimer's \& Dementia 11, 718-726.

Bherer L, Erickson KI, Liu-Ambrose T (2013). A review of the effects of physical activity and exercise on cognitive and brain functions in older adults. Journal of Aging Research 2013.

Bielak AA (2010). How can we not 'lose it' if we still don't understand how to 'use it'? Unanswered questions about the influence of activity participation on cognitive performance in older age-a mini-review. Gerontology 56, 507-519.

Bielak AA, Cherbuin N, Bunce D, Anstey KJ (2014). Preserved differentiation between physical activity and cognitive performance across young, middle, and older adulthood over 8 years. Journals of Gerontology Series B: Psychological Sciences and Social Sciences 69, 523-532.

Blondell SJ, Hammersley-Mather R, Veerman JL (2014). Does physical activity prevent cognitive decline and dementia? A systematic review and meta-analysis of longitudinal studies. BMC Public Health 14, 510.

*Booth T, Deary IJ, Starr JM (2013a). Thyroid stimulating hormone, free thyroxine and cognitive ability in old age: the Lothian birth cohort study 1936. Psychoneuroendocrinology 38, 597-601.

*Booth T, Royle NA, Corley J, Gow AJ, Hernández MDCV, Maniega SM, Ritchie SJ, Bastin ME, Starr JM, Wardlaw JM, Deary IJ (2015). Association of allostatic load with brain structure and cognitive ability in later life. Neurobiology of Aging 36, 1390-1399.

*Booth T, Starr JM, Deary IJ (2013b). Modeling multisystem biological risk in later life: allostatic load in the Lothian Birth Cohort study 1936. American Journal of Human Biology 25, 538-543.

+Bourne VJ, Fox HC, Deary IJ, Whalley LJ (2007). Does childhood intelligence predict variation in cognitive change in later life? Personality and Individual Differences 42, 1551-1559.

Boyle PA, Yu L, Wilson RS, Gamble K, Buchman AS, Bennett DA (2012). Poor decision making is a consequence of cognitive decline among older persons without Alzheimer's disease or mild cognitive impairment. PLOS ONE 7, e43647.

Brayne C (2007). The elephant in the room - healthy brains in later life, epidemiology and public health. Nature Reviews Neuroscience 8, 233-239.

*Brett CE, Gow AJ, Corley J, Pattie A, Starr JM, Deary IJ (2012). Psychosocial factors and health as determinants of quality of life in community-dwelling older adults. Quality of Life Research 21, 505-516. 
*Butchart C, Kyle J, McNeill G, Corley J, Gow A, Starr JM, Deary IJ (2011). Flavonoid intake in relation to cognitive function in later life in the Lothian Birth Cohort 1936. British Journal of Nutrition 106, 141-148.

Carlson MC, Helms MJ, Steffens DC, Burke JR, Potter GG, Plassman BL (2008). Midlife activity predicts risk of dementia in older male twin pairs. Alzheimer's and Dementia 4, 324-331.

‡Carpentieri JD, Elliot J, Brett C, Deary I (2016). Adding narratives to numbers in a mixed methods study of successful ageing: the 6-day sample of the Scottish Mental Survey 1947. Sociological Research Online 21, 8.

‡Carpentieri JD, Elliot J, Brett CE, Deary IJ (2017). Adapting to aging: older people talk about their use of selection, optimization, and compensation to maximize wellbeing in the context of physical decline. Journal of Gerontology: Social Sciences 72, 351-361.

Carvalho A, Rea IM, Parimon T, Cusack BJ (2014). Physical activity and cognitive function in individuals over 60 years of age: a systematic review. Clinical Interventions in Aging 9, 82.

Clear J (2015). This Coach Improved Every Tiny Thing by 1 Percent and Here's What Happened (http://jamesclear.com/ marginal-gains). Accessed 9 March 2016.

Clouston SA, Kuh D, Herd P, Elliott J, Richards M, Hofer SM (2012). Benefits of educational attainment on adult fluid cognition: international evidence from three birth cohorts. International Journal of Epidemiology 41, 1729-1736.

*Cole JH, Ritchie SJ, Bastin ME, Valdés-Hernández MC, Maniega SM, Royle N, Corley J, Pattie A, Harris SE, Zhang Q, Wray N, Redmond P, Marioni RE, Starr JM, Cox SR, Wardlaw JM, Sharp DJ, Deary IJ (2017). Brain age predicts mortality. Molecular Psychiatry. doi: 10.1038/ mp.2017.62.

*Corley J, Gow AJ, Starr JM, Deary IJ (2010a). Is body mass index in old age related to cognitive abilities? The Lothian Birth Cohort 1936 study. Psychology and Aging 25, 867875.

*Corley J, Gow AJ, Starr JM, Deary IJ (2012). Smoking, childhood IQ, and cognitive function in old age. Journal of Psychosomatic Research 73, 132-138.

*Corley J, Jia X, Brett CE, Gow AJ, Starr JM, Kyle JAM, McNeill G, Deary IJ (2011). Alcohol intake and cognitive abilities in old age: the Lothian Birth Cohort 1936 study. Neuropsychology 25, 166-175.

*Corley J, Jia X, Kyle JAM, Gow AJ, Brett CE, Starr JM, McNeill G, Deary IJ (2010b). Caffeine consumption and cognitive function at age 70: the Lothian Birth Cohort 1936 study. Psychosomatic Medicine 72, 206-214.

*Corley J, Starr JM, Deary IJ (2015). Serum cholesterol and cognitive functions: the Lothian Birth Cohort 1936. International Psychogeriatrics 27, 439-453.

*Corley J, Starr JM, McNeill G, Deary IJ (2013). Do dietary patterns influence cognitive function in old age? International Psychogeriatrics 25, 1393-1407.

*Cox SR, Bak TH, Allerhand M, Redmond P, Starr JM, Deary IJ, MacPherson SE (2016). Bilingualism, social cognition and executive functions: a tale of chickens and eggs. Neuropsychologia 91, 299-306.
*Cox SR, Bastin ME, Ferguson KJ, Maniega SM, MacPherson SE, Deary IJ, Wardlaw JM, MacLullich AM (2015a). Brain white matter integrity and cortisol in older men: the Lothian Birth Cohort 1936. Neurobiology of Aging 36, 257-264.

*Cox SR, Hernández MDCV, Kim J, Royle NA, MacPherson SE, Ferguson KJ, Maniega SM, Anblagan D, Aribisala BS, Bastin ME, Park J, Starr JM, Deary IJ, MacLullich AMJ, Wardlaw JM (2017). Associations between hippocampal morphology, diffusion characteristics, and salivary cortisol in older men. Psychoneuroendocrinology 78, 151-158.

*Cox SR, MacPherson SE, Ferguson KJ, Royle NA, Maniega SM, Hernández MDCV, Bastin ME, MacLullich AM, Wardlaw JM, Deary IJ (2015b). Does white matter structure or hippocampal volume mediate associations between cortisol and cognitive ageing? Psychoneuroendocrinology 62, 129-137.

Crowe M, Andel R, Pedersen NL, Johansson B, Gatz M (2003). Does participation in leisure activities lead to reduced risk of Alzheimer's disease? A prospective study of Swedish twins. Journals of Gerontology Series B: Psychological Sciences and Social Sciences 58, 249-255.

*Davies G, Armstrong N, Bis JC, Bressler J, Chouraki V, Giddaluru S, Hofer E, Ibrahim-Verbaas CA, Kirin M, Lahti J, van der Lee SJ, Le Hellard S, Liu T, Marioni RE, Oldmeadow C, Postmus I, Smith AV, Smith JA, Thalamuthu A, Thomson R, Vitart V, Wang J, Yu L, Zgaga L, Zhao W, Boxall R, Harris SE, Hill WD, Liewald DC, Luciano M, Adams H, Ames D, Amin N, Amouyel P, Assareh AA, Au R, Becker JT, Beiser A, Berr C, Bertram L, Boerwinkle E, Buckley BM, Campbell H, Corley J, De Jager PL, Dufouil C, Eriksson JG, Espeseth T, Faul JD, Ford I, Generation Scotland, Gottesman RF, Griswold ME, Gudnason V, Harris TB, Heiss C, Hofman A, Holliday EG, Huffman J, Kardia SLR, Kochan N, Knopman DS, Kwok JB, Lambert J-C, Lee T, Li G, Li S-C, Loitfelder M, Lopez OL, Lundervold AJ, Lundqvist A, Mather KA, Mirza SS, Nyberg L, Oostra BA, Palotie A, Papenberg G, Pattie A, Petrovic K, Polasek O, Psaty BM, Redmond P, Reppermund S, Rotter JI, Schmidt H, Schuur M, Schofield PW, Scott RJ, Steen VM, Stott DJ, van Swieten JC, Taylor KD, Trollor J, Trompet S, Uitterlinden AG, Weinstein G, Widen E, Windham BG, Jukema JW, Wright AF, Wright MJ, Yang Q, Amieva H, Attia JR, Bennett DA, Brodaty H, de Craen AJM, Hayward C, Ikram MA, Lindenberger U, Nilsson L-G, Porteous DJ, Räikkönen K, Reinvang I, Rudan I, Sachdev PS, Schmidt R, Schofield PR, Srikanth V, Starr JM, Turner ST, Weir DR, Wilson JF, van Duijn C, Launer L, Fitzpatrick AL, Seshadri S, Mosley Jr TH, Deary IJ (2015). Genetic contributions to variation in general cognitive function: a meta-analysis of genome-wide association studies in the CHARGE consortium $(N=53,949)$. Molecular Psychiatry 20, 183-192.

*Davies G, Tenesa A, Payton A, Yang J, Harris SE, Liewald D, Ke X, Le Hellard S, Chistoforou A, Luciano M, McGhee K, Lopez L, Gow AJ, Corley J, Redmond P, Fox HC, Haggarty P, Whalley LJ, McNeill G, Goddard ME, Espeseth T, Lundervold AJ, Reinvang I, Pickles A, Steen 
VM, Ollier W, Portoeus DJ, Horan M, Starr JM, Pendleton N, Visscher PM, Deary IJ (2011). Genome-wide association studies establish that human intelligence is highly heritable and polygenic. Molecular Psychiatry 16, 996-1005.

Daviglus ML, Bell CC, Berrettini W, Bowen PE, Connolly ES, Cox NJ, Dunbar-Jacob JM, Granieri EC, Hunt G, McGarry K, Patel D, Potosky AL, Sanders-Bush E, Silberberg D, Trevisan M (2010). National Institutes of Health State-of-the-Science Conference Statement: preventing Alzheimer's Disease and Cognitive Decline. NIH Consensus and State-of-the-Science Statements 27, 1-30.

*Deary IJ (2010). Cognitive epidemiology: its rise, its current issues, and its challenges. Personality and Individual Differences 49, 337-343.

*Deary IJ (2014). The stability of intelligence from childhood to old age. Current Directions in Psychological Science 23, 239-245.

*Deary IJ, Bastin ME, Pattie A, Clayden JD, Whalley LJ, Starr JM, Wardlaw JM (2006a). White matter integrity and cognition in childhood and old age. Neurology 66, 505512.

*Deary IJ, Corley J, Gow AJ, Harris SE, Houlihan LM, Marioni RE, Penke L, Rafnsson SB, Starr JM (2009a). Age-associated cognitive decline. British Medical Bulletin 92, 135-152.

*Deary IJ, Der G, Shenkin SD (2005a). Does mother's IQ explain the association between birth weight and cognitive ability in childhood? Intelligence 33, 445-454.

*Deary IJ, Gow AJ, Pattie A, Starr JM (2012a). Cohort profile: the Lothian Birth Cohorts of 1921 and 1936. International Journal of Epidemiology 41, 1576-1584.

*Deary IJ, Harris SE, Fox HC, Hayward C, Wright AF, Starr JM, Whalley LJ (2005b). KLOTHO genotype and cognitive ability in childhood and old age in the same individuals. Neuroscience Letters 378, 22-27.

*Deary IJ, Johnson W, Gow AJ, Pattie A, Brett CE, Bates T, Starr JM (2011). Losing one's grip: a bivariate growth curve model of grip strength and non-verbal reasoning from age 79 to age 87 years in the Lothian Birth Cohort 1921. Journal of Gerontology: Psychological Sciences 66, 699-707.

*Deary IJ, Johnson W, Houlihan LM (2009b). Genetic foundations of human intelligence. Human Genetics 126, 215-232.

*Deary IJ, Pattie A, Starr JM (2013). The stability of intelligence from age 11 to age 90 years: the Lothian Birth Cohort 1921. Psychological Science 24, 2361-2368.

*Deary IJ, Pattie A, Taylor MD, Whiteman MC, Starr JM, Whalley LJ (2003). Smoking and cognitive change from age 11 to age 80. Journal of Neurology, Neurosurgery \& Psychiatry 74, 1006-1007.

Deary IJ, Penke L, Johnson W (2010). The neuroscience of human intelligence differences. Nature Reviews Neuroscience 11, 201-211.

*Deary IJ, Starr JM, MacLennan WJ (1999). Is age kinder to the initially more able? Differential aging of verbal ability in the HOPE study. Intelligence 26, 357-375.

*Deary IJ, Taylor MD, Hart CL, Wilson V, Davey Smith G, Blane D, Starr JM (2005c). Intergenerational social mobility and mid-life status attainment: influences of childhood intelligence, childhood social factors, and education. Intelligence 33, 455-472.

*Deary IJ, Whalley LJ, Batty GD, Starr JM (2006b). Physical fitness and lifetime cognitive change. Neurology 67, 11951200.

*Deary IJ, Whalley LJ, Starr JM (2009c). A Lifetime of Intelligence: Follow-up Studies of the Scottish Mental Surveys of 1932 and 1947. American Psychological Association: Washington, DC.

*Deary IJ, Whiteman MC, Pattie A, Starr JM, Hayward C, Wright AF, Carothers A, Whalley LJ (2002). Ageing: cognitive change and the APOE $\epsilon 4$ allele. Nature 418, 932-932.

*Deary IJ, Whiteman MC, Pattie A, Starr JM, Hayward C, Wright AF, Visscher PM, Tynan MC, Whalley LJ (2004a). Apolipoprotein e gene variability and cognitive functions at age 79: a follow-up of the Scottish mental survey of 1932. Psychology and Aging 19, 367.

*Deary IJ, Whiteman MC, Starr JM, Whalley LJ, Fox HC (2004b). The impact of childhood intelligence on later life: following up the Scottish mental surveys of 1932 and 1947. Journal of Personality and Social Psychology 86, 130-147.

*Deary IJ, Yang J, Davies G, Harris SE, Tenesa A, Liewald D, Luciano M, Lopez LM, Gow AJ, Corley J, Redmond P, Fox HC, Rowe SJ, Haggarty P, McNeill G, Goddard ME, Porteous DJ, Whalley LJ, Starr JM, Visscher PM (2012b). Genetic contributions to stability and change in intelligence from childhood to old age. Nature 482, 212-215.

*Dickie DA, Ritchie SJ, Cox SR, Sakka E, Royle NA, Aribisala BS, Dickie DA, Ritchie SJ, Cox SR, Sakka E, Royle NA, Aribisala BS, Hernández MDCV, Maniega SM, Pattie A, Corley J, Starr JM, Bastin ME, Deary IJ, Wardlaw JM (2016). Vascular risk factors and progression of white matter hyperintensities in the Lothian Birth Cohort 1936. Neurobiology of Aging 42, 116-123.

Erickson KI, Voss MW, Prakash RS, Basak C, Szabo A, Chaddock L, Kim JS, Heo S, Alves H, White SM, Wojcicki TR (2011). Exercise training increases size of hippocampus and improves memory. Proceedings of the National Academy of Sciences 108, 3017-3022.

Féart C, Samieri C, Barberger-Gateau P (2010). Mediterranean diet and cognitive function in older adults. Current Opinion in Clinical Nutrition and Metabolic Care 13, 14-18.

*Field TS, Doubal FN, Johnson W, Backhouse E, McHutchison C, Cox S, Corley J, Pattie A, Gow AJ, Shenkin S, Cvoro V (2016). Early life characteristics and late life burden of cerebral small vessel disease in the Lothian Birth Cohort 1936. Aging 9, 2039-2051.

Finkel D, Andel R, Gatz M, Pederson NL (2009). The role of occupational complexity in trajectories of cognitive aging before and after retirement. Psychology and Aging 24, 563-573.

*Gale CR, Cooper R, Craig L, Elliott J, Kuh D, Richards M, Starr JM, Whalley LJ, Deary IJ (2012). Cognitive function in childhood and lifetime cognitive change in relation to mental wellbeing in four cohorts of older people. PLOS ONE 7, e44860.

Gatz M, Mortimer JA, Fratiglioni L, Johansson B, Berg S, Reynolds CA, Pedersen NL (2006). Potentially modifiable 
risk factors for dementia in identical twins. Alzheimer's $\mathcal{E}$ Dementia 2, 110-117.

Gottesman RF, Rawlings AM, Sharrett AR, Albert M, Alonso A, Bandeen-Roche K, Coker LH, Coresh J, Couper DJ, Griswold ME, Heiss G, Knopman DS, Patel MD, Penman AD, Power MC, Selnes OA, Schneider ALC, Wagenknecht LE, Windham BG, Wruck LM, Mosely TH (2014). Impact of differential attrition on the association of education with cognitive change over 20 years of follow-up the ARIC neurocognitive study. American Journal of Epidemiology, 179, 956-966.

Gow AJ, Avlund K, Mortensen EL (2014). Occupational characteristics and cognitive aging in the Glostrup 1914 Cohort. Journals of Gerontology Series B: Psychological Sciences and Social Sciences 69, 228-236.

*Gow AJ, Bastin ME, Maniega SM, Hernández MCV, Morris Z, Murray C, Royle NA, Starr JM, Deary IJ, Wardlaw JM (2012a). Neuroprotective lifestyles and the aging brain: activity, atrophy, and white matter integrity. Neurology 79, 1802-1808.

* Gow AJ, Corley J, Starr JM, Deary IJ (2012b). Reverse causation in activity-cognitive ability associations: the Lothian Birth Cohort 1936. Psychology and Aging 27, 250-255.

*Gow AJ, Corley J, Starr JM, Deary IJ (2013a). What social network or support factors are associated with cognitive abilities in old age? Gerontology 59, 454-463.

*Gow AJ, Firth CM, Harrison R, Starr JM, Moss P, Deary IJ (2013b). Cytomegalovirus infection and cognitive abilities in old age. Neurobiology of Aging 34, 1846-1852.

*Gow AJ, Johnson W, Mishra G, HALCyon Study Team, Richards M, Kuh D, Deary IJ (2012c). Is age kinder to the initially more able? Yes, and no. Intelligence 40, 49-59.

*Gow AJ, Johnson W, Pattie A, Brett CE, Roberts B, Starr JM, Deary IJ (2011). Stability and change in intelligence from age 11 to ages 70, 79, and 87: the Lothian Birth Cohorts of 1921 and 1936. Psychology and Aging 26, 232-240.

*Gow AJ, Johnson W, Pattie A, Whiteman MC, Starr J, Deary IJ (2008). Mental ability in childhood and cognitive aging. Gerontology 54, 177-186.

Gow AJ, Mortensen EL, Avlund K (2012d). Activity participation and cognitive aging from age 50 to 80 in the Glostrup 1914 cohort. Journal of the American Geriatrics Society 60, 1831-1838.

*Gow AJ, Pattie A, Deary IJ (2017). Lifecourse activity participation from early, mid, and later adulthood as determinants of cognitive aging: the Lothian Birth Cohort 1921. Journals of Gerontology Series B: Psychological Sciences and Social Sciences 72, 25-37.

*Gow AJ, Pattie A, Whiteman MC, Whalley LJ, Deary IJ (2007). Social support and successful aging: investigating the relationships between lifetime cognitive change and life satisfaction. Journal of Individual Differences 28, 103-115.

*Gow AJ, Whiteman MC, Pattie A, Whalley L, Starr J, Deary IJ (2005). Lifetime intellectual function and satisfaction with life in old age: longitudinal cohort study. British Medical Journal 331, 141-142.

Grove BJ, Lim SJ, Gale CR, Shenkin SD (2017). Birth weight and cognitive ability in adulthood: a systematic review and meta-analysis. Intelligence 61, 146-158.
*Hagenaars SP, Harris SE, Clarke T-K, Hall L, Luciano M, Fernandez-Pujals AM, Davies G, Hayward C, Generation Scotland, Starr JM, Porteous DJ, McIntosh AM, Deary IJ (2016). Polygenic risk for coronary artery disease is associated with cognitive ability in older adults. International Journal of Epidemiology 45, 433-440.

*Harris SE, Davies G, Luciano M, Payton A, Fox HC, Haggarty P, Ollier W, Horan M, Porteous DJ, Starr JM, Whalley LJ, Pendleton N, Deary IJ (2014). Polygenic risk for Alzheimer's disease is not associated with cognitive ability or cognitive aging in non-demented older people. Journal of Alzheimer's Disease 39, 565-574.

*Harris SE, Deary IJ, MacIntyre A, Lamb KJ, Radhakrishnan K, Starr JM, Whalley LJ, Shiels PG (2006). The association between telomere length, physical health, cognitive ageing, and mortality in non-demented older people. Neuroscience Letters 406, 260-264.

*Harris SE, Malik R, Marioni R, Campbell A, Seshadri S, Worrall BB, Sudlow CL, Hayward C, Bastin ME, Starr JM, Porteous DJ, Wardlaw JM, Deary IJ (2016a). Polygenic risk for ischaemic stroke is associated with cognitive ability. Neurology 86, 611-618.

${ }^{*}$ Harris SE, Marioni R, Martin-Ruiz C, Pattie A, Gow AJ, Cox S, Corley J, von Zglinicki T, Starr JM, Deary IJ (2016b). Longitudinal telomere length shortening and cognitive and physical decline in later life: the Lothian Birth Cohorts of 1936 and 1921. Mechanisms of Ageing and Development 154, 43-48.

*Harris SE, Martin-Ruiz C, von Zglinicki T, Starr JM, Deary IJ (2012). Telomere length and aging biomarkers in 70-year-olds: the Lothian Birth Cohort 1936. Neurobiology of Aging 33, 1486-14e3.

*Henderson RD, Allerhand M, Patton N, Pattie A, Gow AJ, Dhillon B, Starr JM, Deary IJ (2011). Vision and intelligence at age 83 in the Lothian Birth Cohort 1921. Intelligence 39, 148-154.

*Henstridge CM, Jackson RJ, Kim JM, Herrmann AG, Wright AK, Harris S, Bastin ME, Starr JM, Wardlaw J, Gillingwater TH, Smith C, McKenzie C-A, Cox SR, Deary IJ, Spires-Jones TL (2015). Post-mortem brain analyses of the Lothian Birth Cohort 1936: extending lifetime cognitive and brain phenotyping to the level of the synapse. Acta Neuropathologica Communications 3, 53.

Herring MP, Jacob ML, Suveg C, Dishman RK, O'Connor PJ (2012a). Feasibility of exercise training for the short-term treatment of generalized anxiety disorder: a randomized controlled trial. Psychotherapy and Psychosomatics 81, 21-28.

Herring MP, Puetz TW, O'Connor PJ, Dishman RK (2012b). Effect of exercise training on depressive symptoms among patients with a chronic illness: a systematic review and meta-analysis of randomized controlled trials. Archives of Internal Medicine 172, 101-111.

Hill WD, Hagenaars SP, Marioni RE, Harris SE, Liewald DCM, Davies G, Okbay A, McIntosh AM, Gale CR, Deary IJ (2016). Molecular genetic contributions to social deprivation and household income in UK Biobank. Current Biology 26, 3083-3089.

*Houlihan LM, Harris SE, Luciano M, Gow AJ, Starr JM, Visscher PM, Deary IJ (2009). Replication study of 
candidate genes for cognitive abilities: the Lothian Birth Cohort 1936. Genes, Brain and Behavior 8, 238-247.

Hultsch DF, Hertzog C, Small BJ, Dixon RA (1999). Use it or lose it: engaged lifestyle as a buffer of cognitive decline in aging? Psychology and Aging 14, 245-263.

Jekel K, Damian M, Wattmo C, Hausner L, Bullock R, Connelly PJ, Dubois B, Eriksdotter M, Ewers M, Graessel E, Kramberger MG (2015). Mild cognitive impairment and deficits in instrumental activities of daily living: a systematic review. Alzheimer's Research \& Therapy 7, 17.

*Johnson MR, Shkura K, Langley SR, Delahaye-Duriez A, Srivastava P, Hill WD, Rackham OJ, Davies G, Harris SE, Moreno-Moral A, Rotival M, Speed D, Petrovski S, Katz A, Hayward C, Porteous DJ, Smith BH, Padmanabhan S, Hocking LJ, Starr JM, Liewald DC, Visconti A, Falchi M, Bottolo L, Rossetti T, Danis B, Mazzuferi M, Foerch P, Grote A, Helmstaedter C, Becker AJ, Kaminski RM, Deary IJ, Petretto E (2016). Systems genetics identifies a convergent gene network for cognition and neurodevelopmental disease. Nature Neuroscience 19, 223-232.

*Johnson W, Corley J, Starr JM, Deary IJ (2011).

Psychological and physical health at age 70 in the Lothian Birth Cohort 1936: links with early life IQ, SES, and current cognitive function and neighborhood environment. Health Psychology 30, 1-11.

*Johnson W, Gow AJ, Corley J, Starr JM, Deary IJ (2010). Location in cognitive and residential space at age 70 reflects a lifelong trait over parental and environmental circumstances: the Lothian Birth Cohort 1936. Intelligence 38, 402-411.

*Kachiwala SJ, Harris SE, Wright AF, Hayward C, Starr JM, Whalley LJ, Deary IJ (2005). Genetic influences on oxidative stress and their association with normal cognitive ageing. Neuroscience Letters 386, 116-120.

*Karama S, Bastin ME, Murray C, Royle NA, Penke L, Maniega SM, Gow AJ, Corley J, Valdés Hernández MC, Lewis JD, Rousseau M-E, Lepage C, Fonov V, Collins L, Booth T, Rioux P, Sherif T, Adalat R, Starr JM, Evans AC, Wardlaw JM, Deary IJ (2014). Childhood cognitive ability accounts for associations between cognitive ability and brain cortical thickness in old age. Molecular Psychiatry 19, 555-559.

*Karama S, Ducharme S, Corley J, Choinard-Decorte Starr JM, Wardlaw JM, Bastin M, Deary IJ (2015). Cigarette smoking and thinning of the brain's cortex. Molecular Psychiatry 20, 778-785.

Kuh DJ, Cooper C (1992) Physical activity at 36 years: patterns and childhood predictors in a longitudinal study. Journal of Epidemiology and Community Health 46, 114-119.

*Lapsley H, Pattie A, Starr JM, Deary IJ (2016). Life review in advanced age: qualitative research on the 'start in life' of 90-year-olds in the Lothian Birth Cohort 1921. BMC Geriatrics 16, 74.

*Laude A, Lascaratos G, Henderson RD, Starr JM, Deary IJ, Dhillon B (2013). Retinal nerve fiber layer thickness and cognitive ability in older people: the Lothian Birth Cohort 1936 study. BMC Ophthalmology 13, 28.

*Laukka EJ, Starr JM, Deary IJ (2014). Lower ankle-brachial index is related to worse cognitive performance in old age. Neuropsychology 28, 281-289.
Lautenschlager NT, Cox KL, Flicker L, Foster JK, van Bockxmeer FM, Xiao J, Greenop KR, Almeida OP (2008). Effect of physical activity on cognitive function in older adults at risk for Alzheimer disease: a randomized trial. Journal of the American Medical Association 300, 1027-1037.

Lee Y, Back JH, Kim J, Kim SH, Na DL, Cheong HK, Hong CH, Kim YG (2010). Systematic review of health behavioral risks and cognitive health in older adults. International Psychogeriatrics 22, 174-187.

Leroux JS, Moore S, Richard L, Gauvin L (2012). Physical inactivity mediates the association between the perceived exercising behavior of social network members and obesity: a cross-sectional study. PLOS ONE 7, e46558.

Loef M, Walach H (2012). Fruit, vegetables and prevention of cognitive decline or dementia: a systematic review of cohort studies. Journal of Nutrition, Health \& Aging 16, 626-630.

*Luciano M, Corley J, Cox SR, Hernández MCV, Craig LC, Dickie DA, Karama S, McNeill G, Bastin ME, Wardlaw JM, Deary IJ (2017). Mediterranean-type diet and brain structural change from 73 to 76 years in a Scottish cohort. Neurology, epub 10.1212.

*Luciano M, Gow AJ, Harris SE, Hayward C, Allerhand M, Starr JM, Visscher PM, Deary IJ (2009a). Cognitive ability at age 11 and 70 years, information processing speed, and APOE variation: the Lothian Birth Cohort 1936 study. Psychology and Aging 24, 129-138.

*Luciano M, Gow AJ, Taylor MD, Hayward C, Harris SE, Campbell H, Porteous DJ, Starr JM, Visscher PM, Deary IJ (2009b). Apolipoprotein E is not related to memory abilities at 70 years of age. Behavior Genetics 39, 6-14.

*Luciano M, Marioni RE, Gow AJ, Starr JM, Deary IJ $(2009 c)$. Reverse causation in the association between C-reactive protein and fibrinogen levels and cognitive abilities in an aging sample. Psychosomatic Medicine 71, 404-409.

*Luciano M, Mõttus R, Harris SE, Davies G, Payton A, Ollier WER, Horan MA, Starr JM, Porteous DJ, Pendleton N, Deary IJ (2014). Predicting cognitive ability in ageing cohorts using type 2 diabetes genetic risk. Diabetic Medicine 31, 714-720.

*Lyall DM, Harris SE, Bastin ME, Maniega SM, Murray C, Lutz MW, Saunders AN, Roses AD, Hernández MDCV, Royle NA, Starr JM, Porteous DJ, Wardlaw JM, Deary IJ (2014). Alzheimer's disease susceptibility genes APOE and TOMM40, and brain white matter integrity in the Lothian Birth Cohort 1936. Neurobiology of Aging 35, 1513e25.

*Lyall DM, Lopez LM, Bastin ME, Maniega SM, Penke L, Hernández MDCV, Royle NA, Starr JM, Porteous DJ, Wardlaw JM, Deary IJ (2013a). ADRB2, brain white matter integrity and cognitive ageing in the Lothian Birth Cohort 1936. Behavior Genetics 43, 13-23.

*Lyall DM, Royle NA, Harris SE, Bastin ME, Maniega SM, Murray C, Lutz MW, Saunders AM, Roses AD, del Valdés Hernández MC, Starr JM, Porteous DJ, Wardlaw JM, Deary IJ (2013b). Alzheimer's disease susceptibility genes APOE and TOMM40, and hippocampal volumes in the Lothian birth cohort 1936. PLoS ONE 8, e80513.

*Marioni RE, Davies G, Hayward C, Liewald D, Kerr SM, Campbell A, Luciano M, Smith BH, Padmanabhan S, Hocking LJ, Hastie ND, Wright AF, Porteous DJ, Visscher 
PM, Deary IJ (2014a). Molecular genetic contributions to socioeconomic status and intelligence. Intelligence 44, 26-32. *Marioni RE, Penke L, Davies G, Huffman JE, Hayward C, Deary IJ (2014b). The total burden of rare, non-synonymous exome genetic variants is not associated with childhood or late-life cognitive ability. Proceedings of the Royal Society of London B: Biological Sciences 281, 20140117.

Marioni RE, Shah S, McRae AF, Chen BH, Colicino E, Harris SE, Gibson J, Henders AK, Redmond P, Cox SR, Pattie A, Corley J, Murphy L, Martin NG, Montgomery GW, Feinberg AP, Fallin M, Multhaup ML, Jaffe AE, Joehanes R, Schwartz J, Just AC, Lunetta KL, Murabito JM, Starr JM, Horvath S, Visscher PM, Wray NR, Deary IJ (2015b). DNA methylation age of blood predicts all-cause mortality in later life. Genome Biology 16, 25.

*Marioni RE, Shah S, McRae AF, Ritchie SJ, Muniz-Terrera G, Harris SE, Gibson J, Redmond P, Cox SR, Pattie A, Corley J, Taylor A, Murphy L, Starr JM, Horvath S, Visscher PM, Wray NR, Deary IJ (2015a). The epigenetic clock is associated with physical and cognitive fitness in the Lothian Birth Cohort 1936. International Journal of Epidemiology 44, 1388-1396.

Marks BL, Madden DJ, Bucur B, Provenzale JM, White LE, Cabeza R, Huettel SA (2007). Role of aerobic fitness and aging on cerebral white matter integrity. Annals of the New York Academy of Sciences 1097, 171-174.

Martin GM (2004). Defeating dementia. Nature 431, 247-248.

*McGrory S, Taylor AM, Kirin M, Corley J, Pattie A, Cox SR, Dhillon B, Wardlaw JM, Doubal FN, Starr JM, Trucco E, MacGillivray TJ, Deary IJ (2016). Retinal microvascular network geometry and cognitive abilities in communitydwelling older people: the Lothian Birth Cohort 1936 study. British Journal of Ophthalmology 1-6. http://dx.doi.org/10. 1136/bjophthalmol-2016-309017.

McGue M, Skytthe A, Christensen K (2014). The nature of behavioural correlates of healthy ageing: a twin study of lifestyle in mid to late life. International Journal of Epidemiology 43, 775-782.

*McGurn B, Deary IJ, Starr JM (2008). Childhood cognitive ability and risk of late-onset Alzheimer and vascular dementia. Neurology 71, 1051-1056.

McKee KJ, Schüz B (2015). Psychosocial factors in healthy ageing. Psychology and Health 30, 607-626.

*McIntosh AM, Gow AJ, Luciano M, Davies G, Liewald DC, Harris SE, Corley J, Hall J, Starr JM, Porteous DJ, Tenesa A, Visscher PM, Deary IJ (2013). Polygenic risk for schizophrenia predicts cognitive change between childhood and old age. Biological Psychiatry 73, 938-943.

*McNeill G, Jia X, Whalley LJ, Fox HC, Corley J, Gow AJ, Brett CE, Starr JM, Deary IJ (2011). Antioxidant and B vitamin intake in relation to cognitive function in later life in the Lothian Birth Cohort 1936. European Journal of Clinical Nutrition 65, 619-626.

Mora F (2013). Successful brain aging: plasticity, environmental enrichment, and lifestyle. Dialogues in Clinical Neurosciences 15, 45-52.

Morris MC (2012). Nutritional determinants of cognitive aging and dementia. Proceedings of the Nutrition Society 71, 1-3.

Mortimer JA, Borenstein AR, Gosche KM, Snowdon DA (2005). Very early detection of Alzheimer neuropathology and the role of brain reserve in modifying its clinical expression. Journal of Geriatric Psychiatry and Neurology 18, 218-223.

*Mõttus R, Johnson W, Murray C, Wolf MS, Starr JM, Deary IJ (2014). Towards understanding the links between health literacy and physical health. Health Psychology 33, 164-173.

*Mõttus R, Luciano M, Starr JM, Deary IJ (2013). Diabetes and life-long cognitive ability. Journal of Psychosomatic Research 75, 275-278.

*Mõttus R, Luciano M, Starr JM, McCarthy MI, Deary IJ (2015). Childhood cognitive ability moderates later-life manifestation of type 2 diabetes genetic risk. Health Psychology 34, 915-919.

*Munang L, Starr JM, Whalley L, Deary IJ (2007). Renal function and cognition in the 1932 Scottish Mental Survey Lothian cohort. Age and Ageing 36, 323-325.

*Murray C, Johnson W, Wolf MS, Deary IJ (2011). The association between cognitive ability across the lifespan and health literacy in old age: the Lothian Birth Cohort 1936. Intelligence 39, 178-187.

*Patton N, Pattie A, MacGillivray T, Aslam T, Dhillon B, Gow A, Starr JM, Whalley LJ, Deary IJ (2007). The association between retinal vascular network geometry and cognitive ability in an elderly population. Investigative Ophthalmology \& Visual Science 48, 1995-2000.

*Penke L, Hernandéz MCV, Maniega SM, Gow AJ, Murray C, Starr JM, Bastin ME, Deary IJ, Wardlaw JM (2012a). Brain iron deposits are associated with general cognitive ability and cognitive aging. Neurobiology of Aging 33, 510-517.

*Penke L, Maniega SM, Bastin ME, Hernández MV, Murray C, Royle NA, Starr JM, Wardlaw JM, Deary IJ (2012b). Brain white matter tract integrity as a neural foundation for general intelligence. Molecular Psychiatry 17, 1026-1030.

Peters R, Poulter R, Warner J, Beckett N, Burch L, Bulpitt C (2008). Smoking, dementia and cognitive decline in the elderly, a systematic review. BMC Geriatrics 23, 36.

Plassman BL, Williams JW, Burke JR, Holsinger T, Benjamin S (2010). Systematic review: factors associated with risk for and possible prevention of cognitive decline in later life. Annals of Internal Medicine 153, 182-193.

Plomin R, Deary IJ (2015). Genetics and intelligence differences: five special findings. Molecular Psychiatry 20, 98-108.

Qiu C, Fratiglioni L (2015). A major role for cardiovascular burden in age-related cognitive decline. Nature Reviews Cardiology 12, 267-277.

Räikkönen K, Pesonen AK, Heinonen K, Lahti J, Komsi N, Eriksson JG, Seckl JR, Järvenpää A-L, Strandberg TE (2009). Maternal licorice consumption and detrimental cognitive and psychiatric outcomes in children. American Journal of Epidemiology 170, 1137-1146.

Reid KJ, Baron KG, Lu B, Naylor E, Wolfe L, Zee PC (2010). Aerobic exercise improves self-reported sleep and quality of life in older adults with insomnia. Sleep Medicine 11, 934-940.

Reppermund S, Brodaty H, Crawford JD, Kochan NA, Slavin MJ, Trollor JN, Draper B, Sachdev PS (2011). The relationship of current depressive symptoms and past depression with cognitive impairment and instrumental activities of daily living in an elderly population: the 
Sydney memory and ageing study. Journal of Psychiatric Research 45, 1600-1607.

${ }^{*}$ Ritchie SJ, Bastin ME, Tucker-Drob E, Munoz Maniega S, Engelhardt L, Cox S, Royle N, Gow A, Corley J, Pattie A, Taylor A, Valdés Hernández MDC, Starr JM, Wardlaw JM, Deary IJ (2015a). Coupled changes in brain white matter microstructure and fluid intelligence in later life. Journal of Neuroscience 35, 8672-8682.

*Ritchie SJ, Bates TC, Corley J, McNeill G, Davies G, Liewald DC, Starr JM, Deary IJ (2014). Alcohol consumption and lifetime change in cognitive ability: a gene $\times$ environment interaction study. Age 36, 1493-1502.

* Ritchie SJ, Bates TC, Deary IJ (2015b). Is education associated with improvements in general cognitive ability, or in specific skills? Developmental Psychology 51, 573-582.

*Ritchie SJ, Bates TC, Der G, Starr JM, Deary IJ (2013). Education is associated with higher later life IQ scores, but not with faster cognitive processing speed. Psychology and Aging 28, 515-521.

*Ritchie SJ, Booth T, Valdés Hernandez MC, Corley J, Munoz Maniega S, Gow AJ, Royle NA, Pattie A, Karama S, Starr JM, Bastin ME, Wardlaw JM, Deary IJ (2015c). Beyond a bigger brain: multivariable brain imaging and intelligence. Intelligence 51, 47-56.

*Ritchie SJ, Dickie DA, Cox SR, Valdés Hernández MDC, Corley J, Royle NA, Pattie A, Aribisala BS, Redmond P, Munoz Maniega S, Taylor AM, Sibbett R, Gow AJ, Starr JM, Bastin ME, Wardlaw JM, Deary IJ (2015d). Brain volumetric changes and cognitive ageing during the eighth decade of life. Human Brain Mapping 36, 4910-4925.

${ }^{*}$ Ritchie SJ, Tucker-Drob EM, Cox SR, Corley J, Dykiert D, Redmond P, Pattie A, Taylor AM, Sibbett R, Starr JM, Deary IJ (2016). Predictors of ageing-related decline across multiple cognitive functions. Intelligence 59, 115-126.

*Ritchie SJ, Tucker-Drob EM, Cox SR, Dickie DA, Valdés Hernández MDC, Corley J, Royle NA, Redmond P, Munoz Maniega S, Pattie A, Aribisala BS, Taylor AM, Clarke T-K, Gow AJ, Starr JM, Bastin ME, Wardlaw JM, Deary IJ (2017). Risk and protective factors for structural brain aging in the eighth decade of life. Brain Structure and Function. doi: 10.1007/s00429-017-1414-2.

Rovio S, Spulber G, Nieminen LJ, Niskanen E, Winblad B, Tuomilehto J, Nissinen A, Soininen $\mathbf{H}$, Kivipelto $\mathbf{M}$ (2010). The effect of midlife physical activity on structural brain changes in the elderly. Neurobiology of Aging 31, 1927-1936. http://dx.doi.org/10.1016/j.neurobiolaging.2008. 10.007

* Royle NA, Booth T, Hernández MCV, Penke L, Murray C, Gow AJ, Maniega SM, Starr JM, Bastin ME, Deary IJ, Wardlaw JM (2013). Estimated maximal and current brain volume predict cognitive ability in old age. Neurobiology of Aging 34, 2726-2733.

Salthouse TA (2006). Mental exercise and mental aging: evaluating the validity of the 'use it or lose it' hypothesis. Perspectives on Psychological Science 1, 68-87.

Schaie KW (2005). Developmental Influences on Adult Intelligence: The Seattle Longitudinal Study. Oxford University Press: Oxford.
*Schiepers OJG, Harris SE, Gow AJ, Pattie A, Brett CE, Starr JM, Deary IJ (2012). APOE E4 status predicts age-related cognitive decline in the ninth decade: longitudinal follow-up of the Lothian Birth Cohort 1921. Molecular Psychiatry 17, 315-324.

Shenkin SD, Bastin ME, MacGillivray TJ, Deary IJ, Starr JM, Wardlaw JM (2009a). Birth parameters are associated with late-life white matter integrity in community-dwelling older people. Stroke 40, 1225-1228.

Shenkin SD, Deary IJ, Starr JM (2009b). Birth parameters and cognitive ability in older age: a follow-up study of people born 1921-1926. Gerontology 55, 92-98.

*Shenkin SD, Rivers CS, Deary IJ, Starr JM, Wardlaw JM $(2009 c)$. Maximum (prior) brain size, not atrophy, correlates with cognition in community-dwelling older people: a cross-sectional neuroimaging study. BMC Geriatrics 9, 12.

Shenkin SD, Starr JM, Deary IJ (2004). Birth weight and cognitive ability in childhood: a systematic review. Psychological Bulletin 130, 989-1013.

†Shenkin SD, Starr JM, Pattie A, Rush MA, Whalley LJ, Deary IJ (2001). Birth weight and cognitive function at age 11 years: the Scottish Mental Survey 1932. Archives of Disease in Childhood 85, 189-196.

Sink KM, Espeland MA, Castro CM, Church T, Cohen R, Dodson JA, Guralnik J, Hendrie HC, Jennings J, Katula J, Lopez OL (2015). Effect of a 24-month physical activity intervention vs health education on cognitive outcomes in sedentary older adults: the LIFE randomized trial. Journal of the American Medical Association 314, 781-790.

*Smart EL, Gow AJ, Deary IJ (2014). Occupational complexity and lifetime cognitive abilities. Neurology 83, 2285-2291.

Smith PJ, Blumenthal JA, Hoffman BM, Cooper H, Strauman TA, Welsh-Bohmer K, Browndyke JN, Sherwood A (2010). Aerobic exercise and neurocognitive performance: a meta-analytic review of randomized controlled trials. Psychosomatic Medicine 72, 239-252.

Sofi F, Valecchi D, Bacci D, Abbate R, Gensini GF, Casini A, Macchi C (2011). Physical activity and risk of cognitive decline: a meta-analysis of prospective studies. Journal of Internal Medicine 269, 107-117.

*Staals J, Booth T, Morris Z, Bastin ME, Gow AJ, Corley J, Redmond P, Starr JM, Deary IJ, Wardlaw JM (2015). Total MRI load of cerebral small vessel disease and cognitive ability in older people. Neurobiology of Aging 36, 2806-2811.

tStarr JM, Deary IJ, Fox HC, Whalley LJ (2007). Smoking and cognitive change from age 11 to 66 years: a confirmatory investigation. Addictive Behaviors 32, 63-68.

*Starr JM, McGurn B, Whiteman M, Pattie A, Whalley LJ, Deary IJ (2004a). Life long changes in cognitive ability are associated with prescribed medications in old age. International Journal of Geriatric Psychiatry 19, 327-332.

*Starr JM, Pattie A, Whiteman MC, Deary IJ, Whalley LJ (2005). Vitamin B-12, serum folate, and cognitive change between 11 and 79 years. Journal of Neurology, Neurosurgery E Psychiatry 76, 291-292.

$\ddagger$ Starr JM, Taylor MD, Hart CL, Smith GD, Whalley LJ, Hole DJ, Wilson V, Deary IJ (2004b). Childhood mental 
ability and blood pressure at midlife: linking the Scottish Mental Survey 1932 and the Midspan studies. Journal of Hypertension 22, 893-897.

Stern Y (2002). What is cognitive reserve? Theory and research application of the reserve concept. Journal of the International Neuropsychological Society 8, 448-460.

Stern Y (2012). Cognitive reserve in ageing and Alzheimer's disease. Lancet Neurology 11, 1006-1012.

Tangney CC, Kwasny MJ, Li H, Wilson RS, Evans DA, Morris MC (2011). Adherence to a Mediterranean-type dietary pattern and cognitive decline in a community population. American Journal of Clinical Nutrition 93, 601-607.

$\ddagger$ Taylor MD, Hart CL, Davey Smith G, Starr JM, Hole DJ, Whalley LJ, Wilson V, Deary IJ (2003). Childhood mental ability and smoking cessation in adulthood: prospective observational study linking the Scottish Mental Survey 1932 and the Midspan studies. Journal of Epidemiology and Community Health 57, 464-465.

Tian Q, Erickson KI, Simonsick EM, Aizenstein HJ, Glynn NW, Boudreau RM, Newman AB, Kritchevsky SB, Yaffe K, Harris TB, Rosano C (2014). Physical activity predicts microstructural integrity in memory-related networks in very old adults. Journals of Gerontology Series A: Biological Sciences and Medical Sciences 69, 1284-1290.

Tucker AM, Stern Y (2011). Cognitive reserve in aging. Current Alzheimer Research 8, 354-360.

Tucker-Drob EM (2011). Neurocognitive functions and everyday functions change together in old age.

Neuropsychology 25, 368-377.

*Tucker-Drob EM, Briley DA, Starr JM, Deary IJ (2014). Structure and correlates of cognitive aging in a narrow age cohort. Psychology and Aging 29, 236-249.

Tucker-Drob EM, Johnson KE, Jones RN (2009). The cognitive reserve hypothesis: a longitudinal examination of age-associated declines in reasoning and processing speed. Developmental Psychology 45, 431-446.

Tucker-Drob EM, Salthouse TA (2011). Individual differences in cognitive aging. Wiley-Blackwell Handbook of Individual Differences, 3, 242-267.

*Valdés Hernández MDCV, Allan J, Glatz A, Kyle J, Corley J, Brett CE, Maniega SM, Royle NA, Bastin ME, Starr JM, Deary IJ, Wardlaw JM (2015a). Exploratory analysis of dietary intake and brain iron accumulation detected using magnetic resonance imaging in older individuals: the Lothian Birth Cohort 1936. Journal of Nutrition, Health $\mathcal{E}$ Aging 19, 64-69.

*Valdés Hernández MDCV, Booth T, Murray C, Gow AJ, Penke L, Morris Z, Maniega SM, Royle NA, Aribisala BS, Bastin ME, Starr JM, Deary IJ, Wardlaw JM (2013). Brain white matter damage in aging and cognitive ability in youth and older age. Neurobiology of Aging 34, 2740-2747.

*Valdés Hernández MDCV, Ritchie S, Glatz A, Allerhand M, Maniega SM, Gow AJ, Royle NA, Bastin ME, Starr JM, Deary IJ, Wardlaw JM (2015b). Brain iron deposits and lifespan cognitive ability. AGE 37, 1-13.

van Vliet $P$, van de Water $W$, de Craen AJ, Westendorp RG (2009). The influence of age on the association between cholesterol and cognitive function. Experimental Gerontology 44, 112-122.

*Visscher PM, Tynan M, Whiteman MC, Pattie A, White I, Hayward C, Wright AF, Starr JM, Whalley LJ, Deary IJ (2003). Lack of association between polymorphisms in angiotensin-converting-enzyme and methylenetetrahydrofolate reductase genes and normal cognitive ageing in humans. Neuroscience Letters 347, 175-178.

Voss MW, Heo S, Prakash RS, Erickson KI, Alves H, Chaddock L, Szabo AN, Mailey EL, Wójcicki TR, White SM, Gothe N, McAuley E, Sutton BP, Kramer AF (2013). The influence of aerobic fitness on cerebral white matter integrity and cognitive function in older adults: results of a one-year exercise intervention. Human Brain Mapping 34, 2972-2985.

*Wardlaw JM, Allerhand M, Doubal FN, Hernández MV, Morris Z, Gow AJ, Bastin M, Starr JM, Dennis MS, Deary IJ (2014). Vascular risk factors, large-artery atheroma, and brain white matter hyperintensities. Neurology 82, 13311338.

*Wardlaw JM, Bastin ME, Valdés Hernández MC, Maniega SM, Royle NA, Morris Z, Clayden JD, Sandeman EM, Eadie E, Murray C, Starr JM, Deary IJ (2011). Brain aging, cognition in youth and old age and vascular disease in the Lothian Birth Cohort 1936: rationale, design and methodology of the imaging protocol. International Journal of Stroke 6, 547-559.

Weuve J, Kang JH, Manson JE, Breteler MM, Ware JH, Grodstein F (2004). Physical activity, including walking, and cognitive function in older women. Journal of the American Medical Association 292, 1454-1461.

Whalley LJ, Dick FD, McNeill G (2006). A life-course approach to the aetiology of late-onset dementias. Lancet Neurology 5, 87-96.

tWhalley LJ, Fox HC, Deary IJ, Starr JM (2005). Childhood $\mathrm{IQ}$, smoking, and cognitive change from age 11 to 64 years. Addictive Behaviors 30, 77-88.

tWhalley LJ, Murray AD, Staff RT, Starr JM, Deary IJ, Fox HC, Lemmon H, Duthie SJ, Collins AR, Crawford JR (2011). How the 1932 and 1947 mental surveys of Aberdeen schoolchildren provide a framework to explore the childhood origins of late onset disease and disability. Maturitas 69, 365-372.

Woodward M, Bolton-Smith C, Tunstall-Pedoe H (1994). Deficient health knowledge, diet, and other lifestyles in smokers: is a multifactorial approach required? Preventive Medicine 23, 354-361.

Zahodne LB, Glymour MM, Sparks C, Bontempo D, Dixon RA, MacDonald SW, Manly JJ (2011). Education does not slow cognitive decline with aging: 12-year evidence from the Victoria Longitudinal Study. Journal of the International Neuropsychological Society 17, 1039-1046.

*Zammit A, Starr JM, Johnson WJ, Deary IJ (2012). Profiles of physical, emotional and psychological wellbeing in the Lothian Birth Cohort 1936. BMC Geriatrics 12, 64.

*Zammit AR, Starr JM, Johnson W, Deary IJ (2014). Patterns and associates of cognitive function, psychosocial wellbeing and health in the Lothian Birth Cohort 1936. BMC Geriatrics 14, 53 . 